\title{
5' Termini of Polyoma Virus Early Region Transcripts Synthesized in vivo by Wild-type Virus and Viable Deletion Mutants
}

\author{
Robert Kamen, Parmol' Jat, Richard Treinman† \\ JenNifER Favaloro \\ Transcription Laboratory, Imperial Cancer Research Fund \\ Lomdon WC2A $3 P X$, England \\ ANI \\ WILLIAM R. Fols \\ Department of Biological Chemistry, The University of Michigan \\ Ann Arbor, Mich. 48109, U.S.A.
}

(Received 22 October 1981, and in revised form 23 March 1982)

The $\bar{s}$ termini of polyoma virus early region transcripts synthesized during the productive infection of permissive mouse cells by wild-type or tsa virus, and those expressed in a variety of transformed rodent cell lines, have been mapped on the viral genome. Results were obtained using the $S_{1}$ nuclease and primer extension gel mapping procedures. Principal $5^{\prime}$ ends of cytoplasmic polyadenylated mRNAs in every instance mapped between nucleotides 145 and 156 (numbering according to Soeda et al., 1980) in the DNA sequence, 17 to 28 base-pairs before the translational initiation codon for early proteins and 26 to 37 base-pairs after a sequence agreeing with the TATA box consensus. Our data implied a minimum of two different termini with this region of the genome, at nucleotide $147 \pm 2$ and at $152 \pm 2$. The 5 ' ends at $147 \pm 2$ were particularly common in the mRNA overproduced after thermal inactivation of the large $\mathrm{T}$ protein at late times during infection. The sequences determining the principal $5^{\prime}$ termini. unlike the analogous sequences in the closely related simian virus 40 (SV40), are distinet from these involved in the viral origin of DNA replication.

A number of minor alternative 5' termini of cytoplasmic mRNAs, located both before and after the principal $5^{\prime}$ ends, were also detected of those downstream from the principal termini, one at nucleotide $300 \pm 2$ was prominent. Although this apparent $\tilde{5}^{\prime}$ end is well within the early protein coding sequence, it occurs at a position $31 \pm 2$ base-pairs after a second TATA box. The several minor apparent 5 ' termini mapping upstream of the principal termini occurred primarily in the vicinity of the highly conserved papovavirus DNA replication origin sequence. This sequence includes a third TATA box. Two of the minor 5 ' termini. at $14 \pm 2$ and at $20 \pm 2$, were near the consensus distance from this TATA box. but the others mapped within or before it. Early region mRNA extracted at late times from the cytoplasm of cells infected with wild-type virus. or with tsa virus at the permissive

† Present address: Department of Biochemistry and Molecular Biology. Harvard Iniversity, Cambridge. Mass. 02138 , I.S.A. 
temperature. was usually (but not invariably) enriched for RNA species with apparent 5' termini mapping in the replication origin region, as well as for even longer RNAs. Surh RNAs wert correctly splised and had the normal polvadenylated 3 ends. They were very minor in the cytoplasmic mRNA overproduced after thermal inactivation of the large T protein at late times during infection, but the nuclear RNA from these cells comprised giant species with highly heterogeneous apparent $5^{\prime}$ ends. including predominantly those in the origin region and others further upstream. Nuelear viral RNA from most transformed cell lines lacked the giant species and had principal 5 ' termini in the nt 145 to 156 region. We consider two models to account for the presence of the longer mRNAs in the crtoplasm of infected cells at late times during infection. The first postulates a shift in transcriptional initiation sites to upstream positions because of the repressor' action of the large $T$ protein. The second, which we favour, proposes that the lorger species oreur beacase of inefficient transeniptional temination, which leads to transeription around the entire circular genome and consequently to the eventual accumulation of long cleavage products in the cytoplasm.

We further studied the mRNAs expressed by three viahle deletion mutants (Bendig et al., 1980) that lack all or part of the stouence determining the principal 5 termini and the TATA box that precedes it. These efficiently synthesized early. region mRNA with slightly or highly heterogeneous 5 ends. Two of the mutants (dl-75 and dl-17) produced mRNAs with principal alternative 5 ends located slightly before or after the deletions. The $5^{\prime}$ ends of these mutant mRNAs corresponded to those of very minor transeripts of wild type templates. These results suggest that sequence information other than the TATA box has an important role in specifying the approximate position of m $\mathrm{RNA} 5^{\prime}$ ends.

\section{Introduction}

The early region of polyoma virus DNA is a single transcription unit determining three principal mRNAs (Fig. 1; Kamen et al. 1980b). These messenger RNAs differ in the location and extent of an internal region removed by $\mathrm{RNA}$ splicing. but share common $5^{\prime}$ and $3^{\prime}$ termini. We recently described the cloning and sequencing of partial complementary copies of the mRNAs. which allowed precise assignments of the three different splice junctions (Treisman et al., 198I). Consideration of available open codon reading frames permitted us to determine which messenger encoded each of the three known viral early proteins (Fig, 1). As the first step in the identification of DNA sequence elements that comprise the early region transeriptional promoter, we now present the detailed mapping of the several 5 ' termini of the mRNAs with respect to the known viral DNA sequence (Deininger ef al., 1979: Friedmann et al., 1979: Soeda et al., 1980).

We mapped the 5 ' termini by three independent but complementary approaches. Two indirect procedures, nuclease $s_{1}$ gel mapping (Berk \& Sharp. 1977 : SollnerWebb \& Reeder, 1979; Weaver \& Weissmann, 1979) and reverse transcriptase primer extension (Ghosh et al., 1980a), were used to compare cytoplasmic and nuclear transcripts from cells infected by wild-type virus or by an early region temperature-sensitive mutant under different grow th conditions. The sensitivity of the indirect procedures also permitted us to map accurately the 5 ' ends of viral transcripts in a variety of polyoma virus-transformed cell lines. These results art presented here. No indirest method, however', exactly determines the first nucleotide of a transeript or distinguishes capped from other $\tilde{5}^{\prime}$ termini. This was 


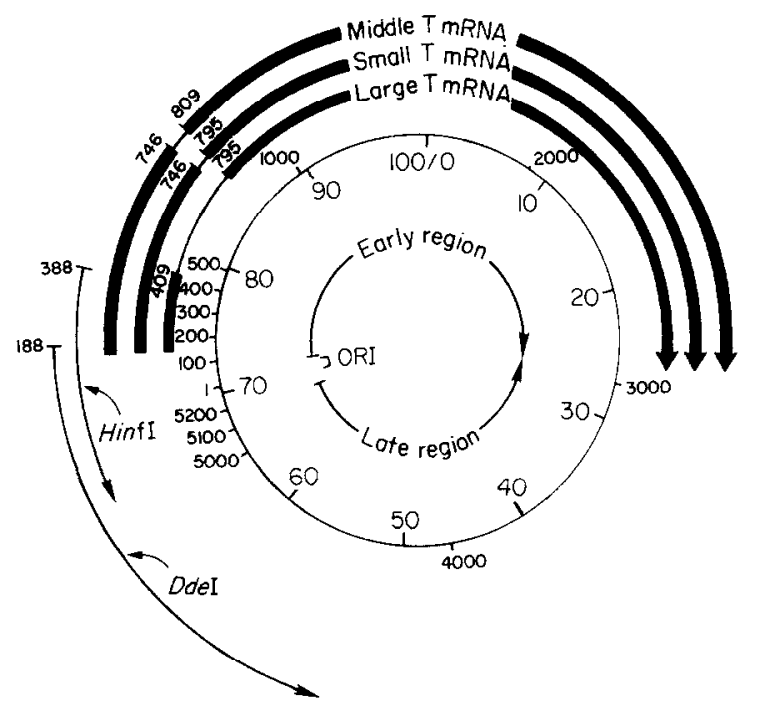

Fic: 1. Map of the principal polyoma virus early region mRNAs. The 3 major spliced mRNAs are oriented around the standard physical map of the viral genomic DNA, with map units (numbers inside the circle) and nucleotide numbers (outside the circle. Soeda et al.. (1980) numbering system) indicated. Splice site assignments are those originally predicted from $S_{1}$ mapping data (Kamen et al.. 1980a,b) and more recently confirmed by sequencing cloned cIDNA copies (Treisman et al. 1981). The two $\left(\tilde{s}_{-}{ }^{32} \mathrm{P}\right)$ labelled. $E$-INA strand, restriction fragments used as hybridization probes (see the text) are positioned with respect to the physical map.

particularly important in the case of the polyoma virus early region transcripts, because the results obtained with indirect procedures suggested terminal heterogeneity. We therefore have further analysed directly the ends of $\left(5^{\prime}-{ }^{32} \mathrm{P}\right)$ labelled viral RNA using the procedure described by Cowie et al. (1981); these experiments will be presented separately (Cowie et al., 1982, accompanying paper). The principal capped 5 ' termini localized by all three approaches mapped within a genomic region previously identified (Bendig et al., 1980) as dispensable for productive viral infection or transformation. It was therefore important to analyse the 5 ' ends of the early region $m$ RNAs synthesized by several of the viable deletion mutants that defined this non-essential region. These experiments showed that neither the Hogness-Goldberg 'I'ATA box, which usually occurs approximately 31 bases before cap sites (for a review, see Breathnach \& Chambon, 1981), nor the wild-type cap sites, are required for efficient viral early gene expression in vivo. The significance of this result in relation to similar findings with other transcription units (Grosschedl \& Birnstiel, 1980a,b; Benoist \& Chambon, 1981 : McKnight et al. . 1981), and with regard to the identity of DNA sequence elements specifying transeriptional initiation. will be discussed.

\section{Materials and Methods}

Much of the methodology used in our laboratory for the study of polyoma virus transcripts has been described in considerable detail (Favaloro t al., 1980). Only further procedures are presented here. 
(a) High-rosolution s, gel mapping using is'-labelled, simgle-stranded rimal restriction fragments

The method used evolved from the Weaver \& Weissmann (1979) moditication of the Berk \& Sharp (1977) procedure. In a typical experiment. $10 \mu \mathrm{g}$ of purified polyoma virus IDNA (strain A2) was digested to completion with either restriction endonuelease $H i n f l$ (Biolabs) or Idel (BRL) using the suppliers' recommended conditions. After extraction with phenol mixture (Favaloro et al. 1980). the DNA was recovered loy precipitation with ethanol. washed with $750^{\circ}$ ethanol, and redissolved in $80 \mu$ of distilled water to which were adderd

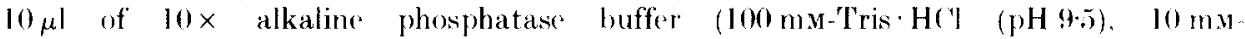
spermidine - H( 7.1 mm-EISTA) and $10 \mu \mathrm{l}$ of a solution of calf intestine alkaline phosphatase (4 units/ml: Bochringer grade I). After ineubation at 37 C for 30 min. the phosphatase was inactivated at 650 ( for $60 \mathrm{~min}$. Dephosphorylated restriction digestions were stored at

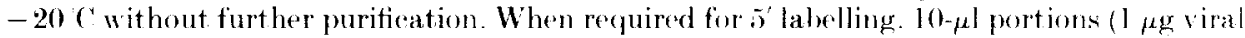

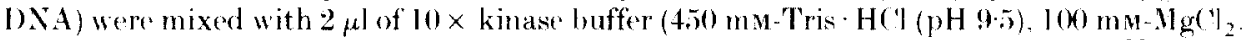

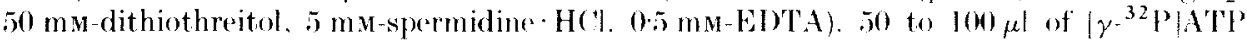

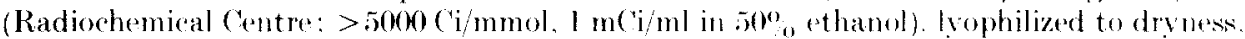
and redissolved in $20 \mu \mathrm{l}$ of distilled water. Phage T4 polyuncleotide kinase (8 to lo buits: P.L. Biochemicals) was then added and after incubation for 1 h at 37 ('. the reaction was

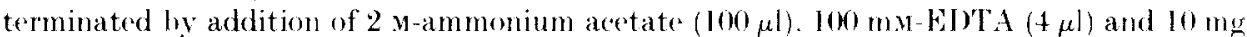
reast RNA carrier/ml $(2 \mu \mathrm{l})$. Protein was removed by extraction with phenol mixt ure. and the labelled INA was reeovered from the aqueous phase by precipitation with ethanol. After reprecipitation from $0.3 \mathrm{~m}$-sodium acetate $(\mathrm{pH} 533)$ and washing in 750 , ethanol. it was dissolved in $14 \mu \mathrm{l}$ of denaturation buffer (Maxam \& (iilbert. 1980: $30 \%$ (r) dimethylsulphoxide. I mM-EDTA ( $\mathrm{pH} 7.5), 0.05 \%$ (w/v) xylene ryanol. $0.05 \%$ (w/v) bromphenol blue) to which was then added a further $6 \mu$ l of undiluted dimethylsulphoxide. The DNA was denatured at 90 ( 9 for' 2 to 3 min and then loaded into a $2 \mathrm{~cm}$ slot on a pre-run strand separation gel $(0-8 \mathrm{~mm} \times 23 \mathrm{~cm} \times 43 \mathrm{~cm})$ containing $5 \%$ (w/v) acrylamide/methylente bisacrylamide (50:I. W/w. prepared as described by $y_{\text {axam }} \&$ (iilbert 1980). The complementary strands of both the 60:3-nucleotide Hinfl and the I(14:3-nucleotide IrdeI fragments used as hybridization probes (see Fig. 1) separated well after electrophoresis at 300 to $400 \mathrm{~V}$ for $24 \mathrm{~h}$. Hybridization of INA eluted from the gests with asymmetrie polyoma virus eomplementary R.NA (Kamen of al. 1976) demonstrated that the sower migrating strand of each of these fragments was the E-IDNA strandt. The yield of labelled IONA fragment was normally $10^{6}$ to $15 \times 10^{6}$ disints/min per single-stranded fragment.

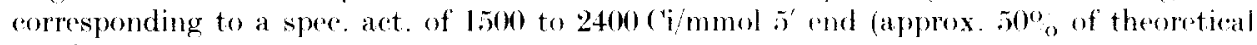
maximum)

Hybridizations and $s_{1}$ nuelease digestions were as previousty described (Favaloro et al.. $1980)$. except that the annealing temperature was $300^{\circ}$. the annealing time was 12 to $16 \mathrm{~h}$. and the $s_{1}$ digestions were normally for $2 \mathrm{~h}$ at $12 \mathrm{C}$. $s_{1}$-resistant IDNA products were fractionated on $5 \%$ or $12 \%,(19: 1 \quad(w / w)$ acrylamide/methylene bisacrylamide) thin area/polvacrylamide gels $(0.3 \mathrm{~mm} \times 23 \mathrm{~cm} \times 43 \mathrm{~cm}$ : Sanger \& coulson. 1978) after denaturation in the formamide buffer used for DNA sequencing (Maxam \& (iilhert. I980) Nize markers used were either (5)- $\left.{ }^{32} \mathrm{P}\right)$-labelled Py lNA Iddel fragments. or samples of the hybridization proble randomly cleaved lefore purine residues (Vaxam \& Gilbert. 1980)

\section{(b) Reverse transeriptase primer extension}

Hybrids between $(5)^{32}$ P)-labelled primer fragments and viral RNA were formed as described above for $S_{1}$ nuclease experiments. Details of primer and RNA quantities used are provided in the Figure legends. After annealing, the hybrids were reeovered by precipitation with ethanol and redissolved in $18 \mu \mathrm{l}$ of a buffer containing $8.3 \mathrm{mu}-\mathrm{HEPES}(\mathrm{pH} 8.3), 6.6 \mathrm{mu}$

† Abbreviations used: $E$-I)NA strand, the loNA strand complementary to early region mRNAs: $l$. IDNA strand. the IDNA strand complementary to late region mRNAs: m. u. map unit(s): nRNA, nuelear RNA : (RNA. the product of transeription of polyoma virus DNA it witro by Escherichia coli RNA polymerase: nt. nucleotide number' bp. base-pair 
dithiothreitol and $66 \mathrm{~mm}-\mathrm{KCl}$. This solution was diluted to a final volume of $30 \mu \mathrm{l}$ containing. in addition, $8 \mathrm{~mm}-\mathrm{MgCl}_{2}, 0.2 \mathrm{~mm}$ each deoxynucleotide triphosphate and 19 units of avian myeloblastosis virus reverse transcriptase (a gift from Dr J. W. Beard). After incubation at $37^{\circ} \mathrm{C}$ for $1 \mathrm{~h}$, the reaction was terminated by addition of EDTA to $10 \mathrm{~mm}$, sodium dodecyl sulphate to $0.1 \%$, ammonium acetate to $1 \mathrm{~m}$ and $10 \mu \mathrm{g}$ of carrier yeast RNA. Protein was extracted with phenol mixture, and the nucleic acids were precipitated from the aqueous phase with ethanol. Subsequent analysis by polyacrylamide/urea gel electrophoresis was as described above for $S_{1}$ nuclease experiments.

\section{Results}

(a) The principal 5' termini of polyoma virus early region $m R$ NAs

Expression of the polyoma virus early region (Cogen, 1978; Kamen et al.. $1980 a, b)$, and that of the closely related simian virus 40 (SV40: Tegtmeyer et al., 1975; Reed et al., 1976; Alwine et al., 1977; Khoury \& May, 1977), is negatively regulated by one of its gene products, the large $T$ protein. During the early phase of productive infection (conventionally defined as that period preceding the onset of viral DNA replication), the predominant nuclear RNA species are $E$-DNA strand transeripts, which are the precursors of early region mRNAs; similarly, only these messengers are detectable in the cytoplasm (see Tooze (1980) for a review of viral transeription in the lytic cycle). During the late phase of productive infection, which follows the onset of viral DNA synthesis, transcription of the complementary $L$-DNA strand becomes increasingly dominant. At 30 hours post-infection, there is at least ten times more late than early region cytoplasmic mRNA. The strong differential expression of $L$-DNA strand transcripts is, at least in part, caused by a regulatory activity of the large $T$ protein. Thermal inactivation of altered forms of this protein containing temperature-sensitive mutations derepresses $E$-DNA strand transeription (Cogen, 1978). Within a few hours after a shift from the permissive to the non-permissive temperature, the abundance of early region mRNAs in the cytoplasm approaches that of the late messengers (Kamen et al., $1980 a, b)$. The repressor activity of purified SV40 large $\mathrm{T}$ protein has been demonstrated directly using transcription systems in vitro (Rio et al., 1980): Myers et al., 1981 ; Hansen et al., 1981).

We exploited this regulatory system to obtain cytoplasmic polyadenylated RNA enriched for viral early region transcripts. Mouse cells were infected with the large T protein mutant tsa (Fried, 1965) and, after 36 hours of grow th at the permissive temperalure, the infected cultures were shifted to the non-permissive temperature four hours before harvesting and RNA extraction. Growth at the permissive temperature allows viral DNA replication to occur, amplifying the transcriptional templates. The subsequent incubation at the non-permissive temperature inactivates the repressor activity of the large $\mathrm{T}$ protein, resulting in the rapid accumulation of early region $m R N A$ in the cytoplasm. We refer to such preparations as tsa shift-up RNA.

The $\bar{s}^{\prime}$ ends of polyoma virus early region $\mathrm{mRNAs}$ were localized on the viral genome, in the first instance, by high-resolution nuclease $s_{1}$ gel mapping. The RNAs were hybridized to two different single-stranded. $\left(5^{\prime}-{ }^{32} \mathrm{P}\right)$-labelled, viral 


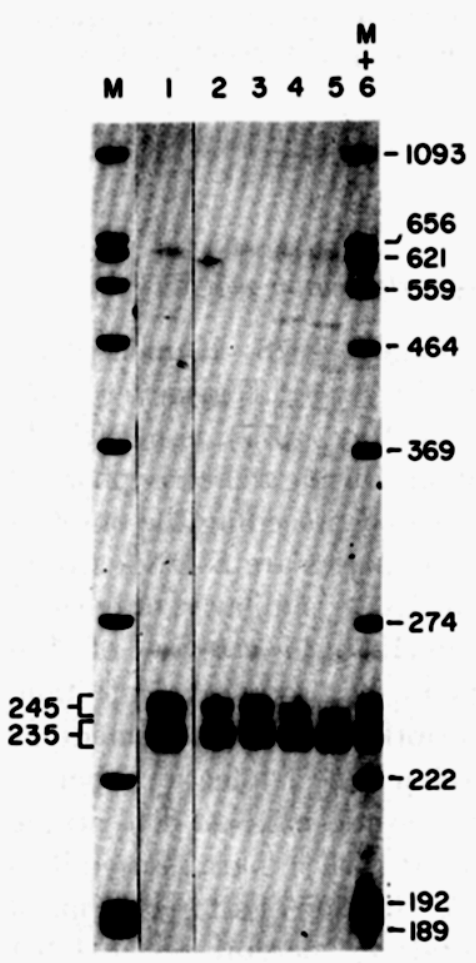

(0)

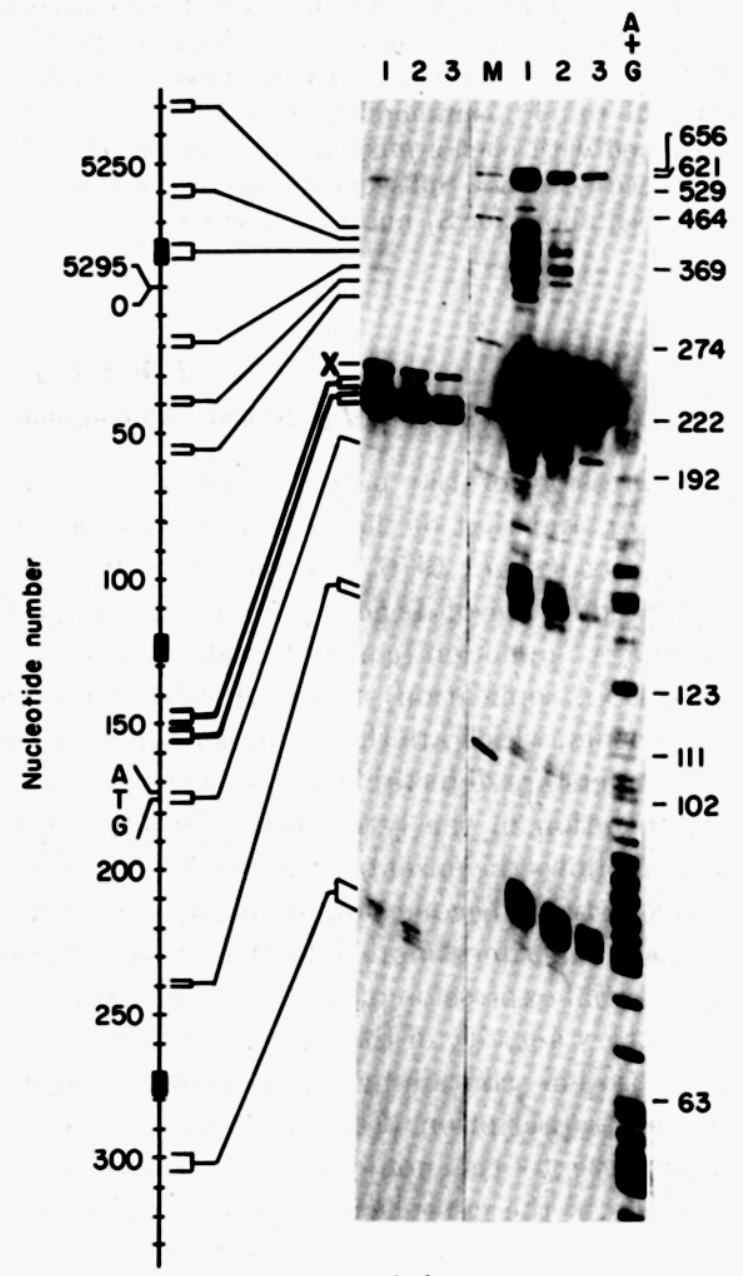

(b)

Fre. 2. Localization of the 5 termini of polvoma virus carly region mRNAs by $x_{1}$ nucleast gel mapping. (a) and (b) Autoradiographs of $5 \%$ polyacryamide/urea gels fractionating $s_{1}$ nuclease resistant $\left(6^{32}{ }^{3}\right)$-labelled I)NA products resulting after the hybridization of various $R N A$ samples from polyoma virus-infected mouse 3 T6 cells to the $H$ infl $E$-i)NA strand probe (1.5 to $2 \cdot 0 \mu(\mathrm{i} / \mathrm{pmol})$ extending clockwise from nucleotides 388 to 5077 (see Fig. 1). The RNA samples used for (a) werr. tracks 1 to 3. 3 different preparations of tsa shift-11p (sep the text) (ytoplasmir polvadenylated RVA $(0.5 .0 \cdot 2$ and $0.5 \mu \mathrm{g}$. respectively); track 4. wild-type mRNA from infected cells grown at $37 \mathrm{C}$ for $30 \mathrm{~h}$ $(1-5 \mu \mathrm{g})$; track 5. mRNA from wild-type-infected cells grown at 39 ( for $30 \mathrm{~h}(3 \mu \mathrm{g})$ : track 6 ( $(0)-$ electrophoresed with the size markers), mRNA from tsa-infected cells grown continuously at 39 (? for

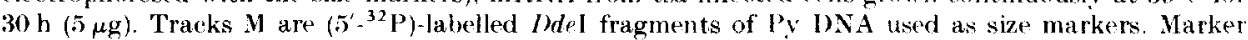
lengths are indicated to the right of the gel, and the ealculated lengths of $s_{1}$-resistant products are indicated to the left. (b) tsa shift-up polyadenylated polysomal mRNA (25.1.0 and $05 \mu \mathrm{g}$, respectively: for tracks 1 to 3). Lighter and darker autoradiographic exposures of the same gel are shown. Alignment of the $S_{1}$-resistant products with the sequeneing track was used to deduce the positions of 5 termini with respect to the viral DNA sequence, as shown to the left of (b). Sequences related to the TATA box consensus (Breathnarh \& Chambon, 1981) are indicated by filled boxes. 
DNA restriction fragment probes. The map positions of the HinfI and DdeI probes used are indicated in Figure 1. After nuclease $S_{1}$ digestion, the resulting hybrids were denatured and the protected single-stranded DNA products were fractionated on polyacrylamide/urea gels. Lengths were determined either from mobilities relative to DNA markers of known size or, more precisely, by comparison with the products of partial degradation of a portion of the hybridization probe by the purine-specific reaction of chemical DNA sequencing (Maxam \& Gilbert. 1980). Data obtained with the HinfI probe are shown in Figures 2, 5 and 6 : those obtained with the DdeI probe are in Figure 4.

Two major $S_{1}$-resistant DNA products were obtained after hybridization of tsa shift-up mRNA to the HinfI DNA probe (Fig. 2(a), tracks 1 to 3 ). These had lengths of approximately 245 and 235 nucleotides, but inspection of the original films clearly indicated that each "band" comprised a group of products with single nucleotide spacing. The mRNA extracted from tsa-infected cells grown continuously at the non-permissive temperature (Fig. 2(a), track 6) yielded a similar result. By contrast, the $\mathrm{mRNA}$ from wild-type-infected cells yielded predominantly the shorter of the two sets of DNA products whether the cells were grown at $37^{\circ} \mathrm{C}$ (Fig. 2(a), track 4 ) or at $39^{\circ} \mathrm{C}$ (Fig. 2(a), track 5). The quantities of mRNA used in this experiment were adjusted to obtain approximately equal protection of the DNA probe, compensating for the difference in abundance between early region mRNAs from wild-type and tsa virus-infected cells (see the legend to Fig. 2).

The same principal $S_{1}$-resistant products were obtained when increasing amounts of polyadenylated RNA purified from the polysomes of tsa shift-up cells were annealed to the HinfI probe (Fig. 2(b)). The band designated $\mathrm{X}$ in this and subsequent Figures is an artifact caused by incomplete nuclease digestion. It can be eliminated preferentially by use of higher enzyme levels (cf. Fig. 6, tracks 1 to 4 ). We attribute its occurrence to the DNA probe folding back on itself to form a short stretch of imperfect DNA-DNA duplex extending the correct length of a DNARNA hybrid. The significance of other minor $S_{1}$-resistant products, particularly apparent in the overexposure of the gel pattern shown to the right of Figure $2(\mathrm{~b})$, is considered separately in section (b), below.

Alignment of the principal $S_{1}$-resistant products with the known viral DNA sequence. as shown in Figure $2(b)$. indicated that major $\delta^{\prime}$ termini mapped at nucleotides 145 to 150 and at 150 to 155 , using the numbering system proposed by soeda et al. (1980). This is some 20 bases before the initiation codon thought to be used for translation of all three viral early proteins (Fig. 2(b)). These approximate assignments were confirmed by the results of the primer extension experiments shown in Figure 3. With a primer DNA fragment labelled at the same Hinf I site as the probe used in the $S_{1}$ nuclease experiments, a pair of extension products with lengths indistinguishable (within the accuracy of this measurement) from the $S_{1}$ resistant products were obtained with tsa shift-up mRNA (Fig 3, trask 2) Correspondingly longer extension products were found using as primer a fragment labelled at a DdeI site 55 bases downstream from the HinfI site (Fig. 3, tracks 8 and $\left.8^{\prime}\right)$. Note that no product corresponding to band $X$ in Figure $2(b)$ was seen in the primer extension studies. 

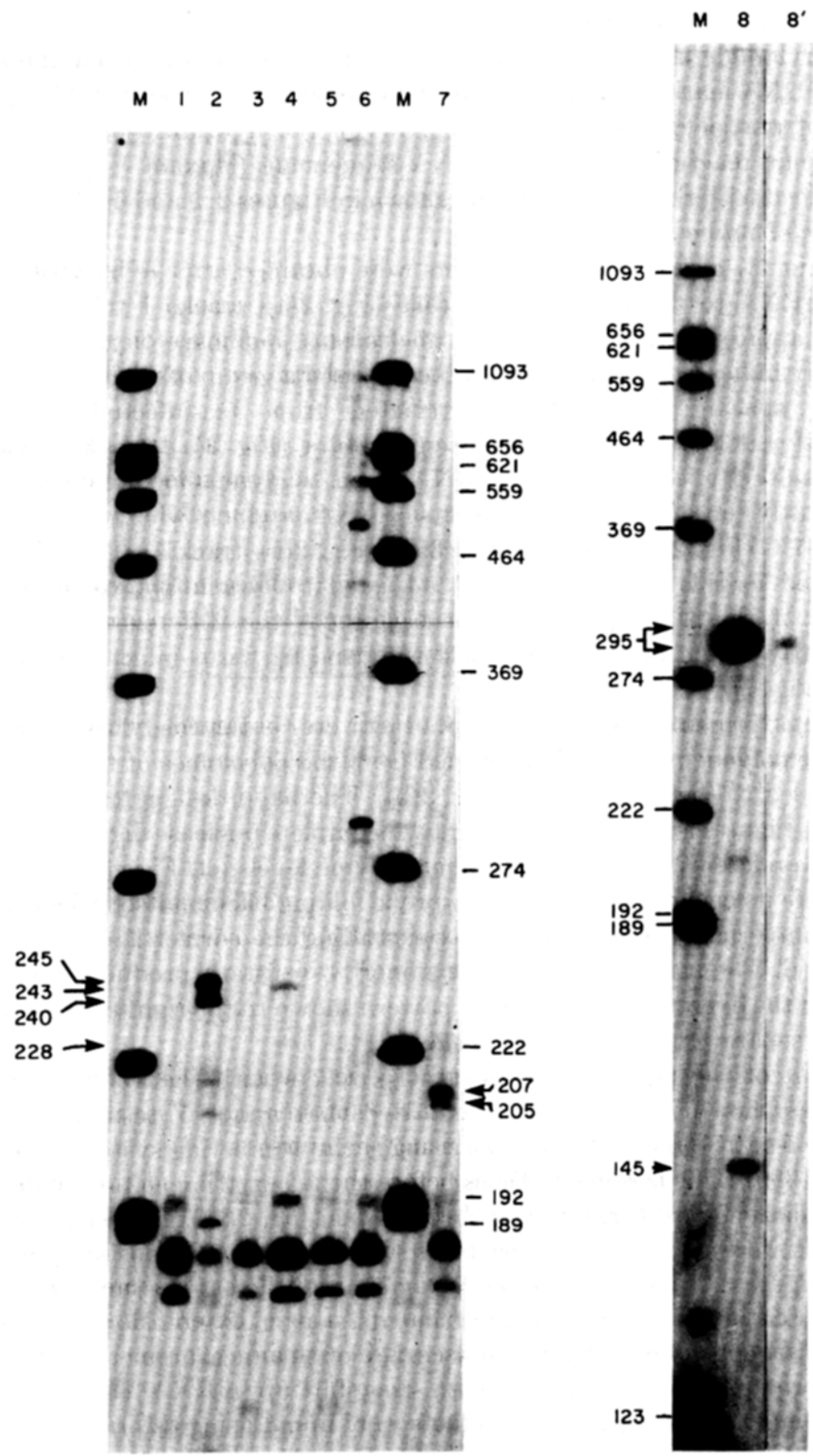

Fiti. 3. 
'To localize the principal 5 ' termini more accurately, we used a DNA probe (the DdeI fragment indicated in Fig. 1) with a $\left(5^{\prime}-{ }^{32} \mathrm{P}\right)$ label much closer to the expected positions. We found a bimodal distribution of products with single nucleotide spacing (Fig. 4, track 3). While it is possible to specify precisely from this experiment the sites of $S_{1}$ nuclease cleavage, exact assignments of mRNA $5^{\prime}$ ends cannot be made because of the ragged DNA $3^{\prime}$ end of one to five bases normally observed after $S_{1}$ nuclease digestion (Sollner-Webb \& Reeder, 1979; Weaver \& Weissmann, 1979; Hentschel et al., 1980). The data with tsa mRNA (Fig. 4, tracks 3,4 and 8 ) strongly suggest, however, that there must be at least two alternative $5^{\prime}$ ends at nt $147 \pm 2$ and at $154 \pm 2$. mRNA from wild-type-infected cells grown at $37^{\circ} \mathrm{C}$ or $39^{\circ} \mathrm{C}$ ( Fig. 4, tracks 1 and 2) apparently had much less of the $5^{\prime}$ end at nt $147 \pm 2$, in agreement with the HinfI results discussed above (Fig. 2(a), tracks 4 and 5). In this experiment (Fig. 4, tracks 5 to 7 ) we also include results obtained with $\mathrm{mRNA}$ extracted from tsa-infected cells after only 12 hours of growth at $32^{\circ} \mathrm{C}$, well before viral DNA replication or late region transcription can be detected. The low abundance of viral sequences in this preparation necessitated the use of rather large amounts of RNA in the annealing reactions. The pattern of $S_{1}$ products closely resembles that of tsa shift-up mRNA (compare tracks 7 and 3 ), but the lengths of the products corresponding to termini at nt $154 \pm 2$ increased by about two nucleotides with increasing RNA level (tracks 5 to 7 ). A similar effect was obtained with tsa shift-up RNA by lowering the $S_{1}$ nuclease levels (data not shown). This suggested that the nuclease, under our standard digestion conditions, removed some of four $\mathrm{rA} \cdot \mathrm{dT}$ or $\mathrm{rU} \cdot \mathrm{dA}$ base-pairs from $\mathrm{nt} 153$ to $\mathrm{ntl} 56$ at the ends of the hybrid structures (see the sequence in Fig. 4), implying that the actual principal 5 ' end might be the A residue corresponding to nucleotide 153 .

Several conclusions can be inferred from the data presented thus far. The principal $5^{\prime}$ ends of polyoma virus early region mRNAs occur approximately 26 to 37 base-pairs, $3^{\prime}$ to a T-A-T-A-A-T-T-A sequence (ntl 20 to ntl27; see Figs 2 and 4) that strongly resembles the Hogness-Goldberg box consensus of T-A-T$\mathrm{A}(\mathrm{A} / \mathrm{T}) \mathrm{A}(\mathrm{T} / \mathrm{A})$ (Breathnach \& Chambon, 1981). The terminal microheterogeneity suggested by our results has also been found for other viral (Baker \& Ziff, 1981: Kahana et al., 1981; Haegeman \& Fiers, 1980; Ghosh \& Lebowitz, 1981) and cellular (Malek et al., 1981; Gretz et al., 1981) genes that have TATA boxes. curiously, when early region transeription is derepressed at late times by the inactivation of the large $\mathrm{T}$ protein, the distribution of $\tilde{\sigma}^{\prime}$ termini among the

Fuc, 3, 5 ' fnd mapping by reverse transcriptase primer extension. (5'-32 P)-labelled viral 1$) \mathrm{NA}$ fragments were hybridized to mRNA and extended with avian myeloblastosis virus reverse transcriptase as described in Materials and Vethods. The extension products were fractionated on 50 . polyacrylamide/urea gels. Tracks 1 to 7 , extension of the $E$-DNA strand of the HinfI to Mbol I IDNA fragment from nt388 to nt267 (approx. 10,000 disints/min per sample). annealed to carrier RNA alone (tracks 1.3 and 5), or to $5 \mu \mathrm{g}$ of tsa shift-up mRNA (track 2), dl $17 \mathrm{mRNA}$ (track 4), d) $2-19 \mathrm{mRNA}$ (track 6 ). and dl $75 \mathrm{mRNA}($ track 7 ). The 3 short extension products seen in the carrier only tracks presumably result from self-priming. Track 8 extension of the $E$-DNA strand of the $D$ deI fragment from nt443 to nt380 (approx. 30.000 disints $/ \mathrm{min}$ ) annealed to $0.5 \mu \mathrm{g}$ of tsa shift-up mRNA. Track 8 is y shorter exposure of track 8 to show that the 295 -nucleotide hand is a doublet. Lengths of $I J d e I$ marke $r$ fragments are indicated to the right in (a) and to the left in (b). ('alculated lengths of extended primers are indicated with arrows. 
alternative positions appears to change in favour of those at $n t 147 \pm 2$. closer to the TATA sequence.

\section{(b) Minor 5' termini of polyoma virus early region $m R V_{+}$s}

Several $s_{1}$-resistant DNA products other than those mapping the principal 5 ends in the nt 145 to $n t 156$ region of the genome were consistently found. The more abundant of these are discussed in this section: consideration of the others is deferred to section (e), below.

In experiments using the HinfI probe (Fig. 2(b), tracks I to 3 : cf. also Fig. 8(a), mRNA track) a group of products approximately 90 bases long was found with every mRNA preparation examined, whether wild-type or mutant. These would map a $5^{\prime}$ end at $n+300 \pm 2$ in the $\mathrm{DNA}$ sequence. The reverse transeriptase primer extension experiment shown in Figure 3 (track 8, the 145-nucleotide band) confirmed that this was a $5^{\prime}$ end rather than a site of internal $s_{1}$ cleavage. Inspection of the preceding DNA sequence revealed $(-\mathrm{A}-\mathrm{T}-\mathrm{A}-\mathrm{T}-\mathrm{A}-\mathrm{A}$ (nt270 to nt276) at the usual distance for a Hogness-Goldberg box before a cap site. RNAs starting from this alternative site would lack the initiation codon (which is at nt 173 to nt 175) believed to be used for translation of the early proteins. They could. however, encode truncated polypeptides not detected thus far. The recovery of minor RNAs with this 5 ' end from polysomes (Fig. $2(b)$ ) indicates that it would be worthwhile to look for such proteins.

Experiments with tsa shift-up mRNA preparations also generated very minor $S_{1}$-resistant DNA products longer than the principal ones. These include a complex set of DXA products that would map at least nine 5 'ends between nt5230 and nt5260 (Fig. 2(b). particularly the darker exposure of track 1. where the RNA was in excess relative to the probe DNA: see also faint bands near the top of the gel shown in Fig. 4, tracks 3 and 4). The locations of these putative 5 ends can be deduced more accurately from the gels shown in Figure 12 , and are indicated in Figure 14. There was also RNA that protected nearly the full length of the Hinfl

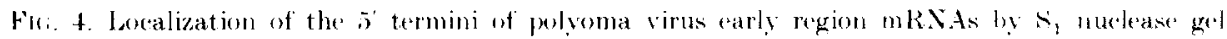
mapping using the Idel probe (sec Fig. 1) ('ytoplasmie polyadenylated mRXA from polvoma rirus

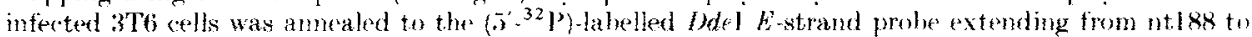

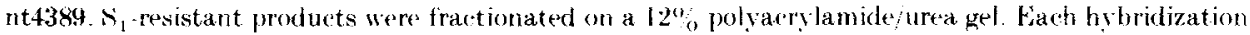
contained approx. $15 \mathrm{ng}$ of DNA fragment (spece. act. $2 \cdot 2 \mu(\mathrm{i} / \mathrm{pmol})$ and the following RNA samples track 1 . is $\mu \mathrm{g}$ of RXA from wild-type-infected cells grown for 30 h at 37 (': track 2 , i $\mu \mathrm{g}$ of $\mathrm{R} N \mathrm{~A}$ from

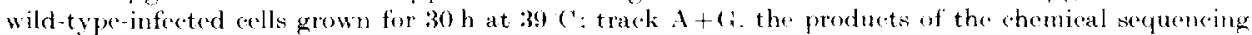
$\mathrm{A}+\mathrm{C}$ reaction (Maxam \& (iibert. 1980$)$ done on a portion of the probe fragment to provide homologous length markers: track 3 . I $\mu \mathrm{g}$ of tsa shift-up) mRNA: track 4,5 $\mu \mathrm{g}$ of $\mathrm{mRNA}$ from mRNA from twainferted cells grown continuously for 30 h at 39 (': tracks 5 through 7 are 5.10 and $20 \mu \mathrm{g}$, respectively of mRNA from cells infected with tsa virus. grown at 32 ( 9 and harested $12 \mathrm{~h}$ post-infection; tract $x$. $1 \mu \mathrm{g}$ of polysomal polyadenylated mRNA from tsa shift-up cells: traeks M. polyoma IINA IJdeI size markem. The sequence shown to the left of the autoradiogram uses the $\mathrm{A}+$ ci track marker fragments to align the $S_{1}$-resistant IONA fragment lengths with the INA secpener of the whand with the same sense as the early region mRNAs. Arrows indieate the positions of putative mRNA 5' termini. In making these assignments. We have corrected (Sollner-Wel)b \& Reeder. 1979) for the fact that the chenical reactions cleave 5 to the purine nucleotides leaving 3 -phosphate termini, whereas the $s_{1}$-resistant J)NA products

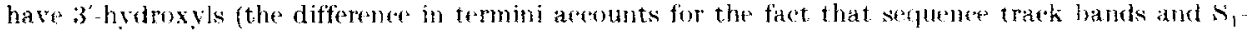
resistant prenducto do not eomigrate preceisty). 


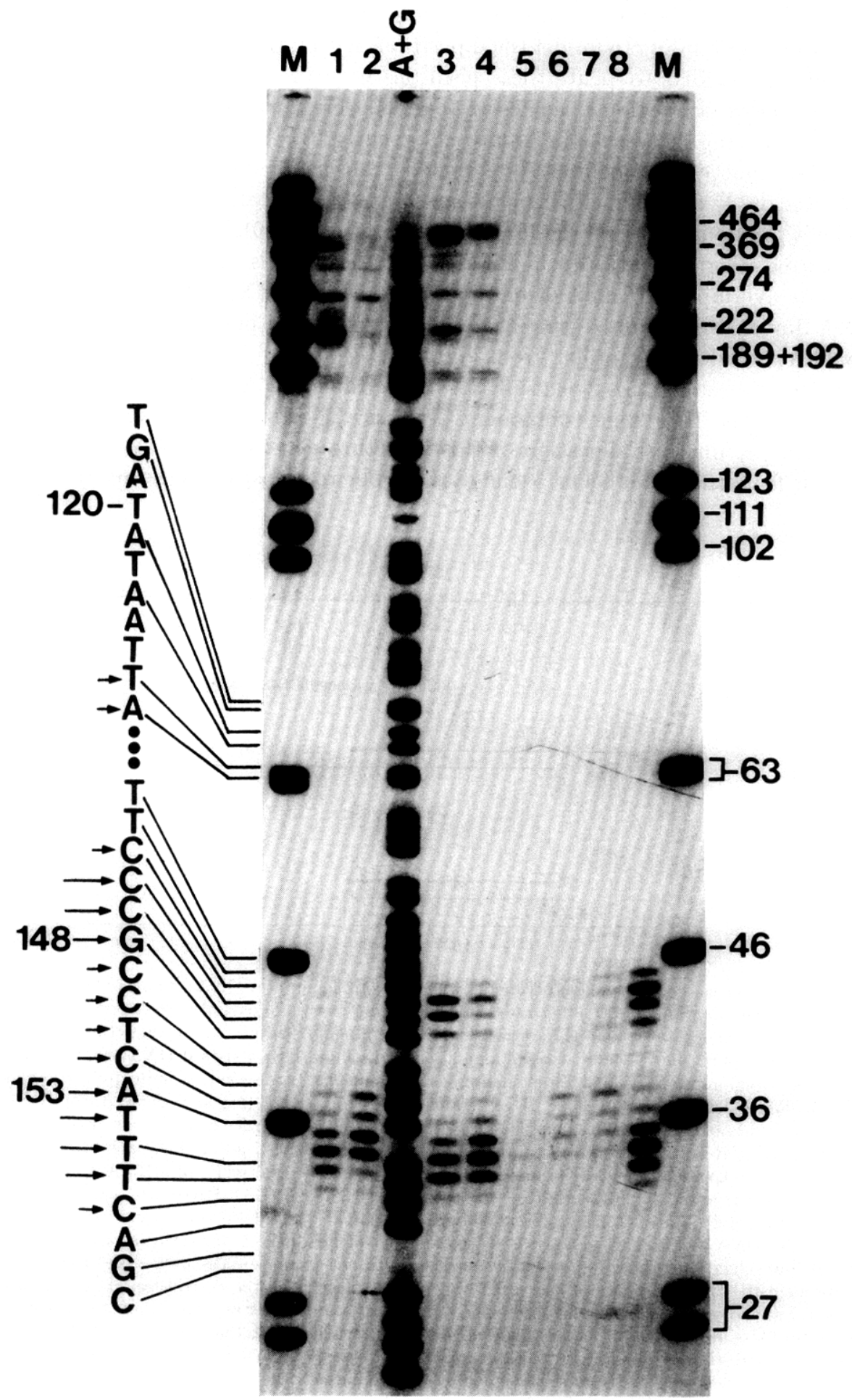

Fig. 4. 
probe (Fig. 2(b), dark exposure). indicating that there are further minor species with 5 ' ends extending to unidentified positions within the late region of the genome (see Fig. 1). Efforts to locate these positions with the IDdeI probe (Fig. 4), which contains more late region sequence (cf. Fig. 1), were unsuccessful because of RNARNA annealing between the minor long early RNAs and the 5 portions of abundant but complementary late region transeripts. Such RNA-RNA partial duplexes, in $S_{1}$ mapping experiments, generate $S_{1}$-resistant $\mathrm{DNA}$ products. which we have previously termed shadows (Favaloro et al., 1980). The origin of shadows is illustrated diagrammatically in Figure 5 . If the 5 ' ends of the minor long early mRNAs overlap the $5^{\prime}$ ends of more abundant late mRNAs. the region of RNA $\mathrm{RNA}$ duplex that forms during the annealing reaction prevents the ${ }^{32} \mathrm{P}$-labelled. single-stranded DNA probe from hybridizing up to the $\bar{s}^{\prime}$ end of its $\mathrm{RNA}$ complement (see Fig. 5). Because RNA-RNA duplexes are more stable than INA RNA hybrids, the triple component structure shown in the diagram is highly favoured. $S_{1}$ nuclease digestion of this structure generates a DNA product that extends from the ${ }^{32} \mathrm{P}$-labelled 5 ' end of the probe to a position determined by the $5^{\prime}$

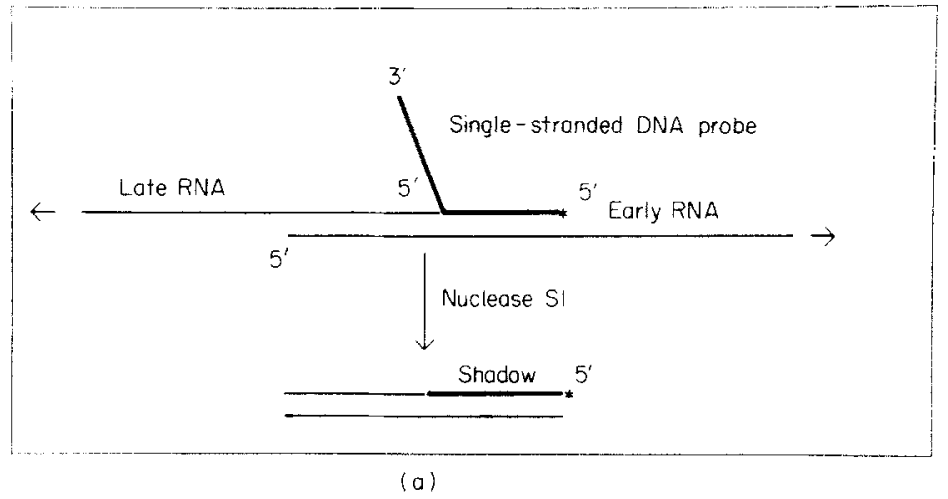

FIt:5. S, nuclease gel mapping experiments with the complementary DNA strands of the Hinf I INA fragment. The diagram in (a) illustrates bow annealing between partially overlapping symmetric. transeripts ean generate croneous $S_{1}$-resistant DXA products (shadows. as explained in the toxt). (b) 'The aut cradiograph shows control experiments used to distinguish $\aleph_{1}$-resistant INA geoducts mapping

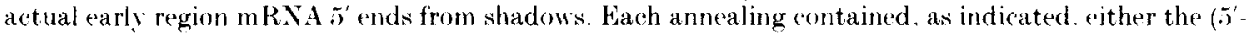
${ }^{32}$ P)-labelled E-IDNA strand or the L-DNA strand of the Hinf DNA fragment derived from wild-type or deletion mutant DNAs (probes homologous to the RNAs were used : the deletion mutants (cf. Fig. 10) are discussed in Results, section (e) ) and the following mRNAs: lanes 1 and $2.1 \mu \mathrm{g}$ cach from 2 different tsa shift-up preparations: lanes $3,4,5$ and $6.1,5.25$ and $5 \mu \mathrm{g}$. respectively of inRNA from wild-typinfected cells harvested $30 \mathrm{~h}$ post-infection : lanes 7 and $8.0 \% \mu \mathrm{g}$ of $\mathrm{d} 175 \mathrm{mRNA}$ harvested at $30 \mathrm{~h} ;$ lanes 9 and $10.1 \mu \mathrm{g}$ of $\mathrm{d}] 17 \mathrm{mRNA}$ harvested at $30 \mathrm{~h}$. A $12 \%$ polyacrylamide/urea gel was used to fractionate $S_{1}$-resistant I)NA Lanes marked $S$ are $\mathrm{A}+($ S sequencing tracks for the $E$ or $L-I) N A$ strands (SE and $S L$ ) of each hrbridization probe. Lanes $M$ are markers with the chain lengths indicated to the left. The' positions in the IDNA sequenee of late mRNA 5 ' ends deduefed from the $\mathrm{S}_{1}$-resistant. INA products in lanes 6.7 and 10 are shown with arrows to the right. The data demonstrate that there ex ist insufficient amounts of late $m$ RNA with 5' ends extending doser to the early region than $n$ t5172 to produce shadows interfering with the mapping of early region $m R N A$ s' termini downtream (with respet to the early. region) of this pesition. Note that the appasent low abundance of late region mRNA is beatuse the major late $\bar{a}^{\prime}$ ends (Cowie at al. In8I) ocour tom close to the end of the probe to form stable hybrids. 
end of the late RNA strand of the hybrid, rather than to the position of the $\tilde{5}^{\prime}$ end of the early mRNA that hybridized to the probe. We therefore identify this product as a shadow of the late mRNA $5^{\prime}$ end. Its detection would clearly demonstrate the occurrence of an early mRNA that overlapped the 5 ' end of the late mRNA, but its length would not position the $5^{\prime}$ end of this early RNA. In order to distinguish shadows from DNA products mapping $5^{\prime}$ ends of RNAs complementary to the

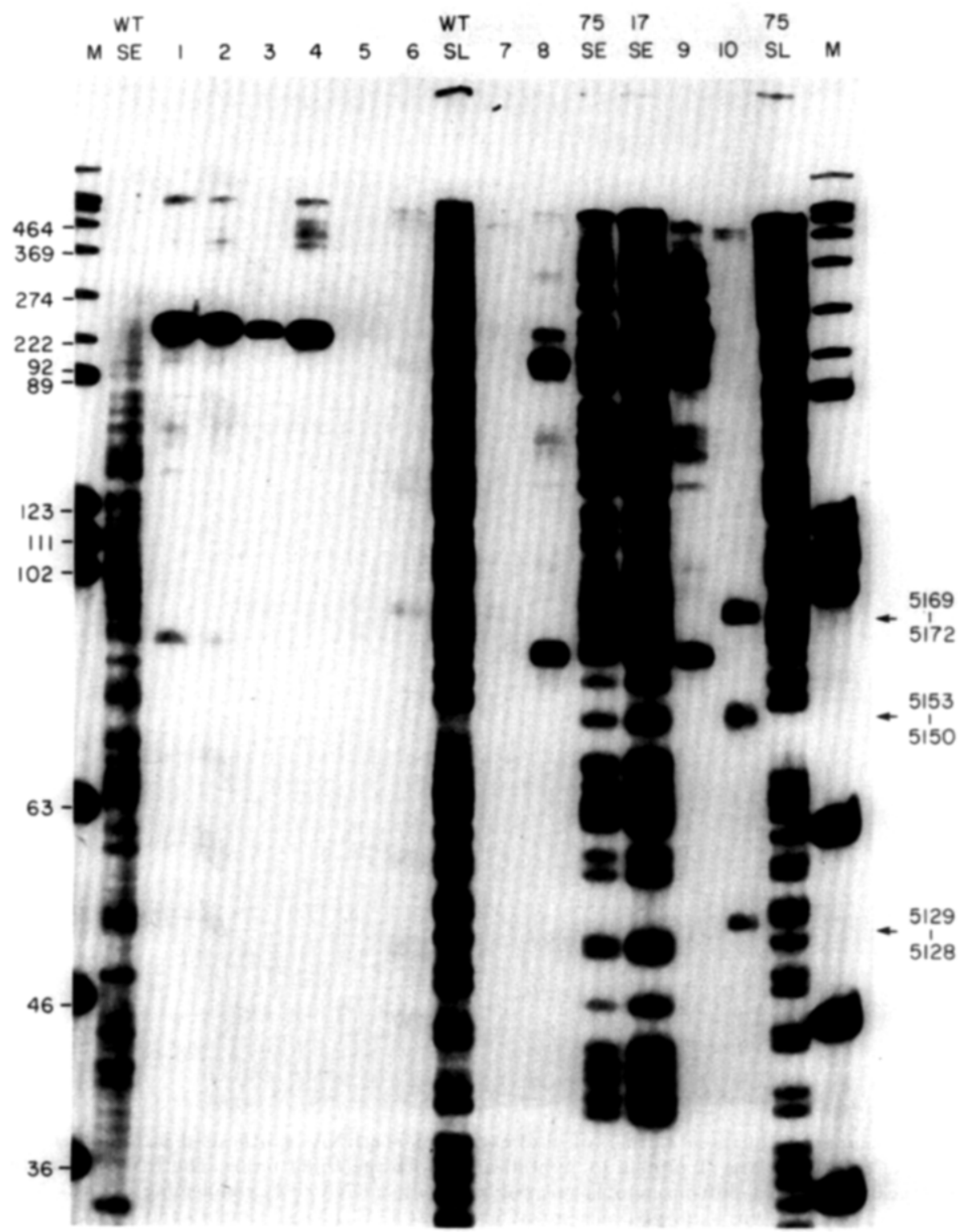

Fic. 5(b). 


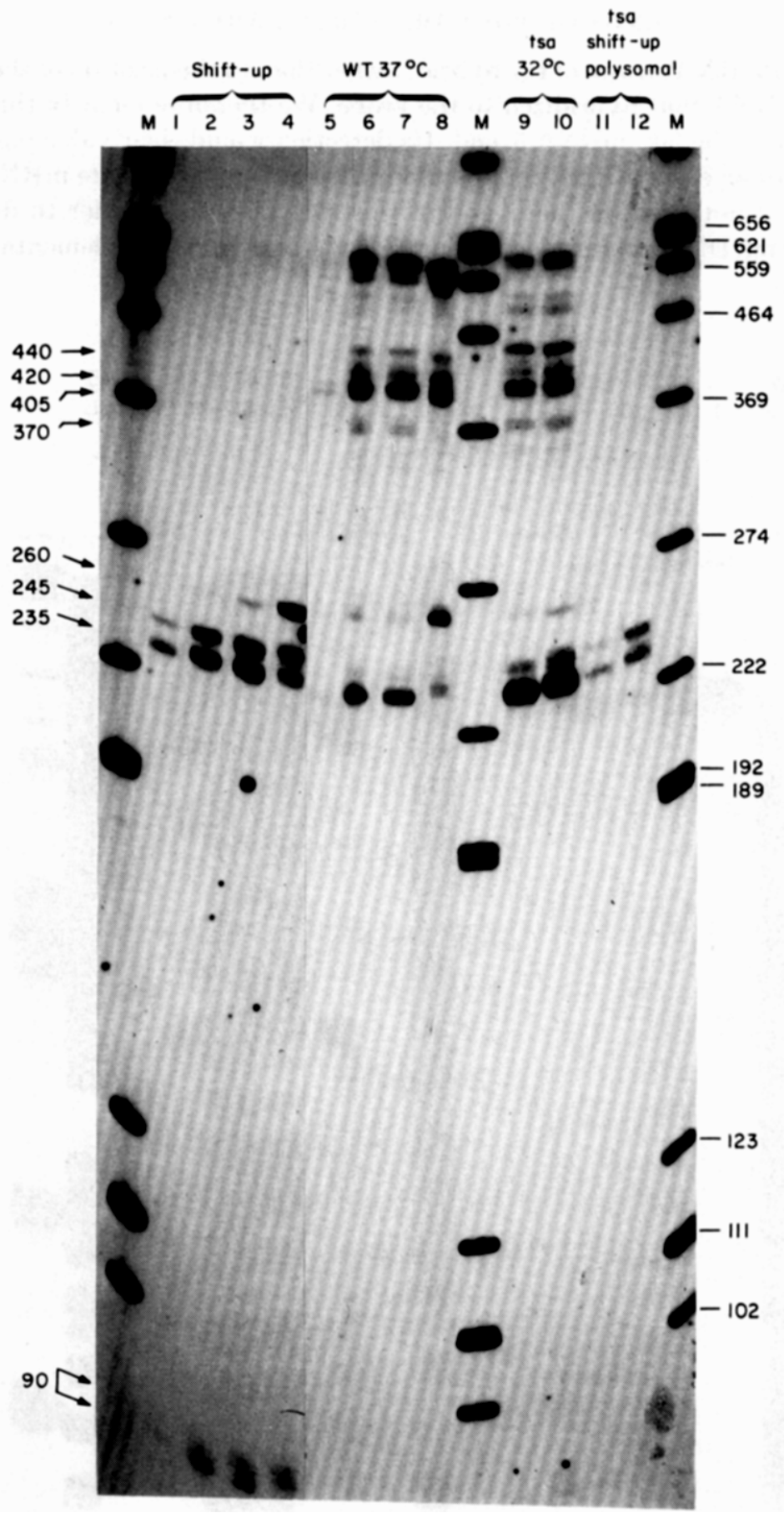

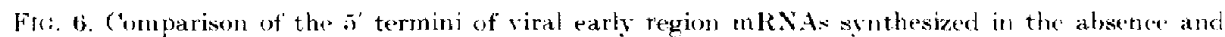
presenes of functional large T protein by hybidization with the Hinfl probe. The RXA preparations

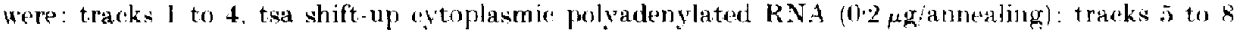

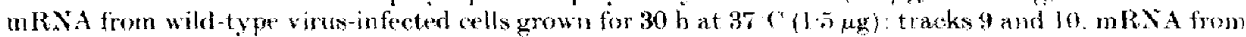
tsa-infected cells grown at 32 ( extracted before the temperat ure shift $(1 \mu \mathrm{g}):$ tracks 11 and 12 . tsa shiftup polyomal polyadenylated on RNA. All s, nucledse digestions were at 12 ( for $2 \mathrm{~h}$, using the following

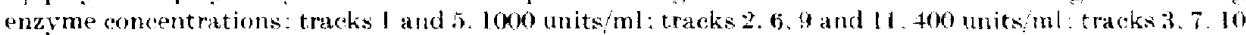

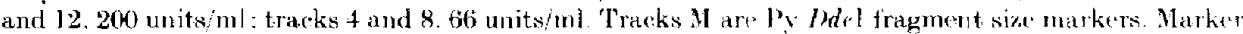
lengths are listed on the right. and deduced lengths of $S_{1}$-resistant preducts on the left. 
probe DNA strand, it is necessary to separately hybridize both strands of the DNA probe to the RNA sample. An example of such an experiment is also shown in Figure 5. Here we annealed the $E$ and the $L$-DNA strand of the Hinf I probe (see Fig. 1) to tsa shift-up RNA (tracks 1 and 2) or to RNA from wild-type virusinfected cells harvested 30 hours post-infection (tracks 3 to 6 ). The results obtained with the $E$-DNA strand (tracks 1 to 4 ) are equivalent to those shown above in Figure 2. With the $L$-DNA strand probe (tracks 5 and 6), we detected only three relatively minor DNA products (the smallest is best seen in track 10). These map the 5 ' ends of late mRNAs closest to the early region at nt5169 to nt5172, nt5150 to nt5153 and nt5128 to nt5129 (Treisman, 1980). The several major 5' ends of late mRNAs are further from the early region (Cowie et al. 1981) and are not detected with the Hinf I probe, either because they occur beyond it or too close to the 5 ' label to form nuclease-resistant hybrid. We can conclude from the experiment shown in Figure 5 that there are no $5^{\prime}$ ends of late mRNAs closer to the early region than nt5180 that are sufficiently abundant to cast shadow's. However. we would expect to detect them beyond nt5170. We also include in Figure 5 similar control experiments for RNA extracted from cells infected with two of the viable deletion mutants (tracks 7 to 10) discussed in section (e), below.

Returning to our discussion of the localization of the $5^{\prime}$ termini of the minor longer mRNAs detected in tsa shift-up RNAs, we infer that with the DdeI probe (Fig. 4, track 3), the longest $s_{1}$-resistant product (apparently mapping a 5 ' end at approx. nt5075) is a shadow of the $5^{\prime}$ end of the repeated leader unit (Treisman. $1980)$ present at the beginning of each late mRNA; similarly. the two fainter bands below the longest one on this gel are shadows corresponding to the late mRNA $s^{\prime}$ ends detected in Figure 5. track 6. We can therefore conclude from these experiments only that some minor RNA molecules have 5 ' ends that extend into the late region of the genome.

Early region mRNAs with 5 ' termini mapping upstream of the principal ones were always very minor in tsa shift-up mRNA preparations. Indeed, they were detected in $S_{1}$ experiments only under conditions of relative RNA excess (Fig. $2(b)$. track 3) and were not apparent in other experiments (Fig. 2(b), track 1: Fig. 6. tracks 1 to 4, 11 and 12) where band intensity was proportional to RNA abundance because the probe DNA was in excess. By contrast, early region polyadenylated RNA extracted at 30 hours post-infection from the cytoplasm of cells infected with wild-type virus was commonly enriched for RNA with the upstream 5 termini (Fig. 6, tracks 5 to 8 ), as was the RNA from tsa-infected cells harvested after 36 hours at $32^{\circ} \mathrm{C}$. just before the temperature shift (Fig. 6. tracks 9 and 10). We established by the two-dimensional $s_{1}$ gel mapping experiments shown in Figure 7 (see the legend for a detailed description of these and their interpretations) that at least a substantial proportion of the longer RNAs were correctly spliced and had the normal polyadenylated $3^{\prime}$ end. The possible origin and significance of these RNA species is considered further in the Diseussion. We note here, however, that among a large number of RNA preparations made in his laboratory during the past few years, the $y$ ield of the longer species has been rather variable and indeed in some preparations of late RNA from wild-type cells harvested at 30 hours postinfertion these RNAs were minor (for example. Fig. 5. tracks 3 and 4). 

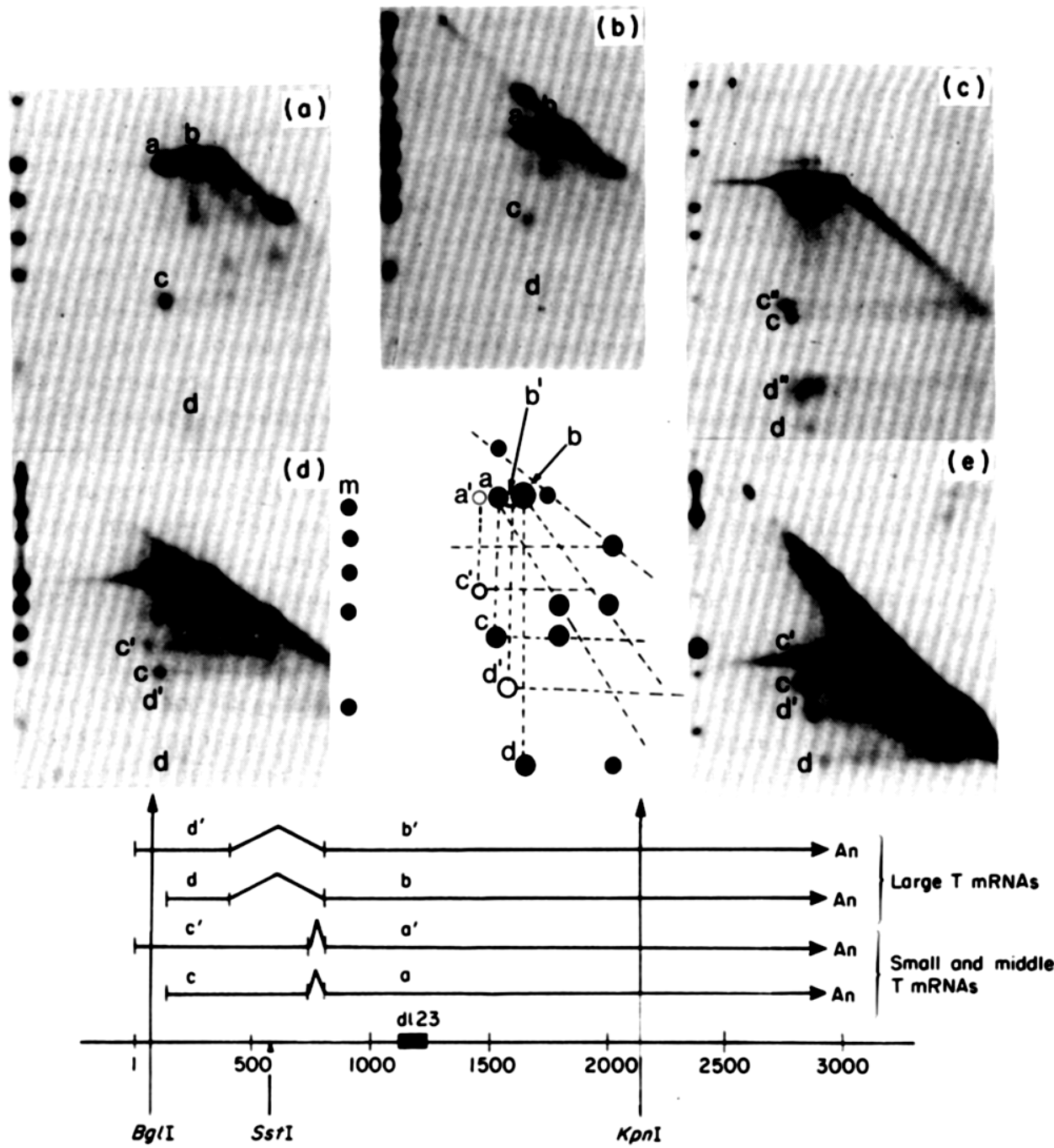

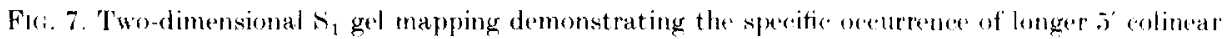
segments in the early region mRNAs produced at late times of lytic infection. The theory and practice of the 2-dimemsional method were described by Favaloro if al. (1980). (a) to (o) Autoradiograms of nitrocellulose filter transfers from 2 -dimensional agarose gols separating $S_{1}$-resistant DNA products.

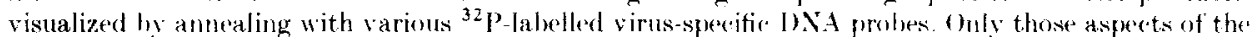
patterns pertinent to the $\vec{s}$-terminal colinear segments are discussed bere. although all features of the a utoradiograms ran le interpreted to generate structural maps of the principal and minor carle region mRNAs (see Treisman t al. I981). (a) tsa shift-up polysomal RNA hybridized to unlabelled restriction fragment $K p n I-1$ (nt4693 (lockwise to nt2176: of. Fig. 1): transfer annealed to nick-translated viral I)NA. 'The spets along the left edge of this and all other panels are Hpall viral restriction fragments loaded in the seeond (alkaline) dimension as size markers. Spots designated at and e correspond to the 3 ' and $s^{\prime}$ colmear regions of the small and middle $T$ proteins mRNAs. respertively as shown in the line

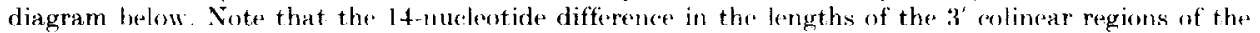
small and middle' T protein mRNAs ('Treisman et al. 1981) is not resolved on the agarose gels. Spots 1 ,

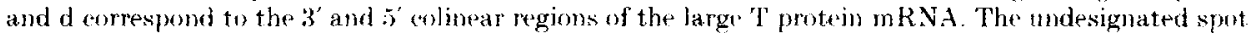
adjacent to spot b is caused by $\mathrm{S}_{1}$ (leavage of the RNA strand of hybrids opposite the excised DNA loop, Other spots relate to minor species (Kamen et al. 1980ab: Treisman ef al., l981) irrelevant to the present concerns. (b) mRNA from tsa-infected cells grown at the nor-permissive temperature (39) (a) for 
(c) The 5' termini of nuclear RNA molecules

Nuclease $S_{1}$ gel mapping experiments similar to those already described were also attempted with nuclear RNA. At late times of wild-type infection, there is such a large excess of continuous transcripts of the entire $L$-DNA strand that RNARNA self-annealing effectively prevents detection of $E$-DNA strand transcripts (Fig. 8(b), tracks 4 to 7 ; cf. Kamen et al., 1974). At very early times of infection, there was too little viral nuclear $R$ NA for fine-structure $S_{1}$ mapping experiments. Useful results, however, were obtained with tsa shift-up nRNA, because under these conditions transcription of both DNA strands occurs at similar rates. The data shown in Figure 8 reveal significant quantitative and qualitative differences between tsa shift-up nRNA and mRNA. We were surprised to find that very similar amounts of $S_{1}$-resistant DNA were obtained with $0 \cdot 1 \mu \mathrm{g}$ of total nuclear RNA (nRNA track in Fig. 8(a)) and $0 \cdot 3 \mu \mathrm{g}$ of poly(A)-selected cytoplasmic RNA (mRNA track in Fig. 8(a)). More extensive quantitation of the $\mathrm{S}_{1}$-resistant DNA produced as a function of RNA concentration (data not shown), after correction for the relative recovery of cellular RNA in the total nuclear and cytoplasmic polyadenylated fractions, demonstrated that there was at least ten times more viral nRNA than polyadenylated eytoplasmic mRNA. This result did not reflect inefficient polyadenylation, because virtually all of the viral cytoplasmic RNA was recovered in the polyadenylated fraction. The predominant $S_{1}$ products obtained

30 h. hybridized to the KpnI-1 IDNA fragment; transfer annealed to ${ }^{32}$ P-labelled $L$-strand I)NA (cD)NA complementary to asymmetric cRNA; Favaloro et al. 1980). The pattern is the same as in (a) (except for the spot along the diagonal above spot a. which corresponds to unspliced RNA). Comparison of' (a) and (b) demonstrates that all transcripts detected were complementary $w$ the E-IDNA strand and. further. that the mRNA overproduced by inactivation of large $T$ protein have the same structures as those synthesized in the absence of large $T$ protein before the initiation of DNA replication. (c) $m R N A$ prepared at a late time during infection hybridized to full-length linear IDNA cleaved by restriction endonuclease $B g l I$ at a point (nt 93 ) about 55 nucleotides upstream of the map positions of the principal 5 termini of mRNAs (see line diagram) synthesized under tsa shift-up conditions. The pattern was visualized with ${ }^{32} \mathrm{P}$-labelled $L$-strand $\mathrm{DNA}$. The features of interest. in comparison with the results in (a) and (b). are the 2 spots. $c^{\prime \prime}$ and $d^{\prime \prime}$. just above and to the left of spots c and $d$. Theste additional spots represent longer alternative 5 'colinear segments of normally spliced mRNAs. The lengths of products $c^{\prime \prime}$ and $\mathrm{d}^{\prime \prime}$ (some 50 nucleotides longer than corresponding products $c$ and d) suggest that they extend from the $B g / I$ site to the splice joins. The experiment shown in (c) used RNA from cells infected with viable deletion mutant dl 23 (map position shown in the line diagram; ( iriffin \& Maddock. 1979) because the pattern obtained was particularly photogenic. However. the same results were obtained with RNA rxtracted at late times during infection from cells infected with wild-type virus and have nothing to do with the deletion mutation. This point is proved in (d) and (c). (d) mRNA from tsa-infected ceells grown at the permissive temperature for $37 \mathrm{~h}$, hybridized to $K$ phI-1 INA : the probe was nick-translated viral DNA. Spots e' and d' correspond to 's' colinear segments of small and middle 'T mRNAs (c') and large 'T $m R N^{+}$s $\left(d^{\prime}\right)$ some 150 nucleotides longer than those represented by e and d. (Comparison of this result with that shown in (c) (spots $e^{\prime \prime}$ and $\mathrm{d}^{\prime \prime}$ ) proves that INA products $e^{\prime}$ and d' extend across the Bg/I site. (e) mRNA from wild-type virus-infected cells grown at 37 C for 30 h, hybridized to $K p n I-1$ INA; the probe here was a nick-translated plasmid containing viral restriction fragment $\$ s t l-2$ (nt-434l clockwise to the site at $n t 569$ shown in the line diagram. including only the sequenees complementary to 5 portion of the early region). Spots $e^{\prime}$ and e corresponding to alternative 5 ' segments of small plus middle $T$ $m R N A s$, and $\mathrm{d}^{\prime}$ and $\mathrm{d}$, corresponding to those of large $\mathrm{T} \mathrm{mRN}$ As. are apparent. The detection of these spots with the Sstl-2 probe confirms the map positions shown in the line diagram: note that the : 3 ' colinear portions of the mRNAs are not detected with this probe. and that other spots along the overexposed diagonal correspond to the late region mRNAs. 


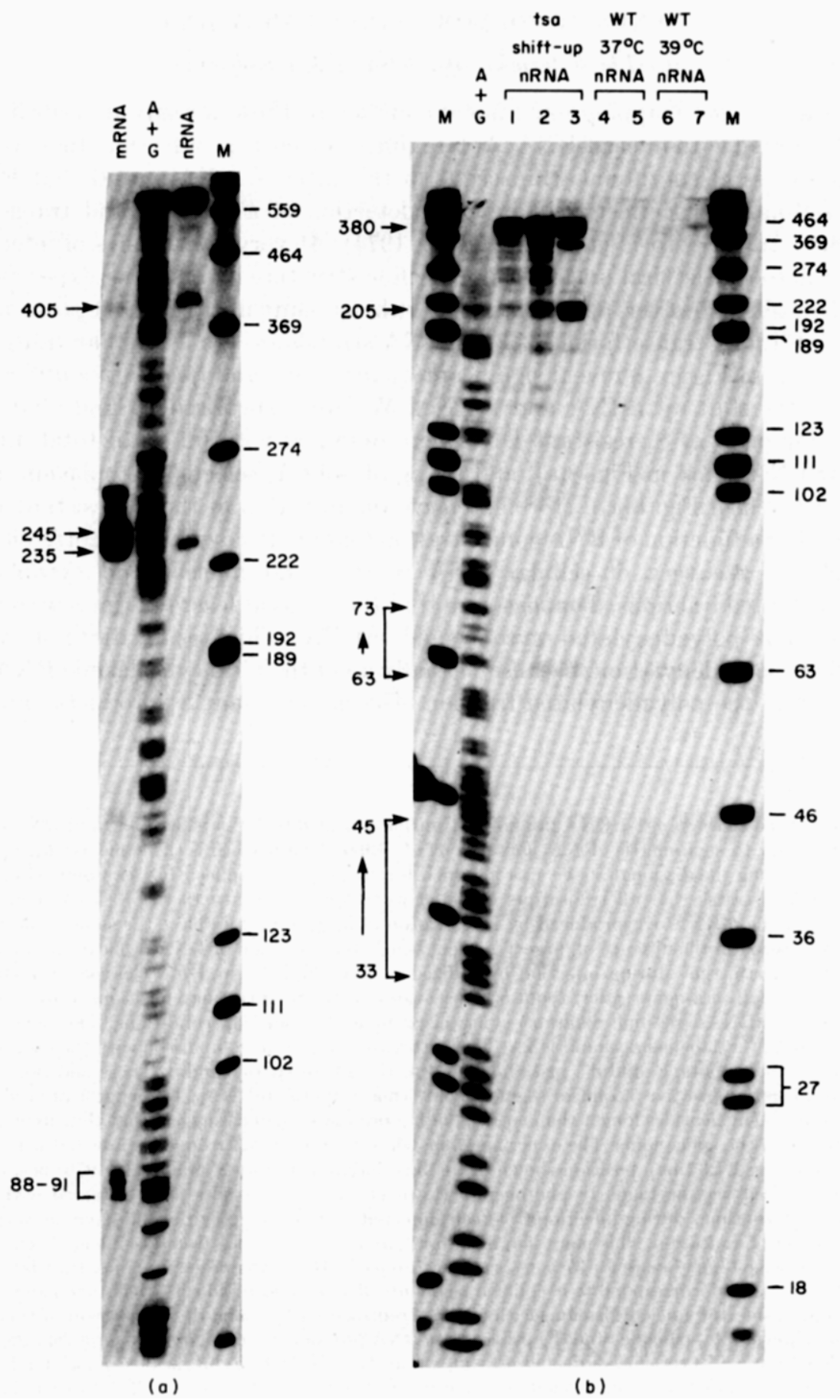

Fla: 8. comparion of the s' termini of cytoplasmic mRNA and total nuctear RN.A by $\mathrm{S}_{1}$ gel mapping asing (a) the Hinfl or (b) the IdeI I)NA probes. The quantities of tsa shift-up RNA used in (a) werte $0 \cdot 3 \mu \mathrm{g}$ of eytoplasmic polyadenylated $\mathrm{mRNA}$ and $0.1 \mu \mathrm{g}$ of total nuclear RXA. (b) Tracks I to 3 . 0.(k). 0.125 and $2 \cdot 0 \mu \mathrm{g}$ tsa shift-up total nuclear RNA tracks 4 and $5,2 \%$ and $5 \mu \mathrm{g}$ of total nuclear RNA from

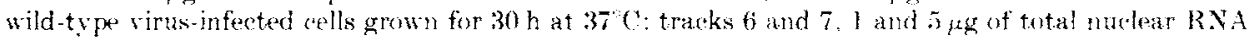
from wild-type virus-infexted eells grown at 39 (' for $30 \mathrm{~h}$. 
with the abundant nRNA were full-length protection of the HinfI DNA probe (Fig. 8(a)) and a 380-nucleotide band (Fig. 8(b)) with the DdeI probe. The 380nucleotide product is the shadow of the repeat unit in the leaders of late mRNA precursors. DNA products (the 245 and $235 \mathrm{nt}$ bands in Fig. 8(a)), nRNA track, and the 63 to $73 \mathrm{nt}$ bands in Fig. 8(b)) corresponding to the principal $5^{\prime}$ ends of mRNAs were detected with nRNA, but they were minor and enriched for the ntl53 $\pm 25^{\prime}$ end. The $205 \mathrm{nt}$ band seen principally under conditions of $n$ RNA excess (Fig. 8(b), track 3) with the DdeI probe, and the corresponding 405 nt band found with the HinfI probe (Fig. 8(a)) may result from $\mathrm{S}_{1}$ cleavage at eight $\mathrm{rU} \cdot \mathrm{dA}$ pairs back from nt5268 to nt5275 (see Fig. 14) within continuous DNA-RNA hybrids (Hansen et al., 1981).

Our interpretation of these $\mathrm{nRNA}$ results is based on the observation that at late times of productive infection, the entire $E$-DNA strand of the viral genome is transcribed to yield giant tandemly repeated transcripts (Kamen et al., 1974: Acheson \& Mieville, 1978). From the ratio of cytoplasmic to nuclear RNA, we conclude that only a small fraction of this RNA is exported. We presume, but have not proved, that the original $5^{\prime}$ end is capped and that only the first copy of the early region, after cleavage and polyadenylation, matures to become $\mathrm{mRNA}$. The rest of the RNA must be retained in the nuclei for eventual degradation, perhaps through a series of endonucleolytic cleavages. Therefore, the RNA we detect in nuclei could be predominantly these residual sequences rather than $m R N A$ precursors. The complex pattern of minor 5' ends seen with nRNA, under this hypothesis, would be cleavage rather than start sites. To test this possibility. we recently examined the heterogeneous 5 ' ends of tsa shift-up nRNA by direct RNA analysis. We found that only those 5 ' ends corresponding to the principal mRNA cap sites were capped (Cowie et al., 1982, accompanying paper).

\section{(d) The 5' ends of viral cytoplasmic and nuclear RNA in transformed cell lines}

We concluded in a previous report (Kamen et al., 1980b) that the $5^{\prime}$ ends of viral mRNAs expressed in polyoma virus-transformed rodent cell lines mapped within viral sequences at approximately the same positions as the early region mRNAs synthesized during productive infection. This conclusion was confirmed by the high-resolution $S_{1}$ mapping data shown in Figure 9 . All of the transformed rat or mouse cell lines examined had mRNAs with $5^{\prime}$ ends in the nucleotide 145 to 156 region. In other experiments, not shown. we obtained the same results with $\mathrm{mRNA}$ from a set of rat cell lines transformed by recombinant plasmids containing all or part of the polyoma virus early region. This demonstrates that the polyoma virus early promoter functions in the integrated state.

The analysis of viral nRNA in productively infected cells, described in the previous section, was complicated by the circularity of the viral genome and the apparent absence of efficient transcriptional termination. Transformed cell lines, particularly those in which the structure of the integrated viral DNA is wellknown, afford a simpler system with which to ask whether the mRNA 5 ' termini correspond to those of nuclear precursors. We therefore used the $s_{1}$ nuclease method to map the $5^{\prime}$ ends of nuclear viral RNA in a number of transformed rat and 


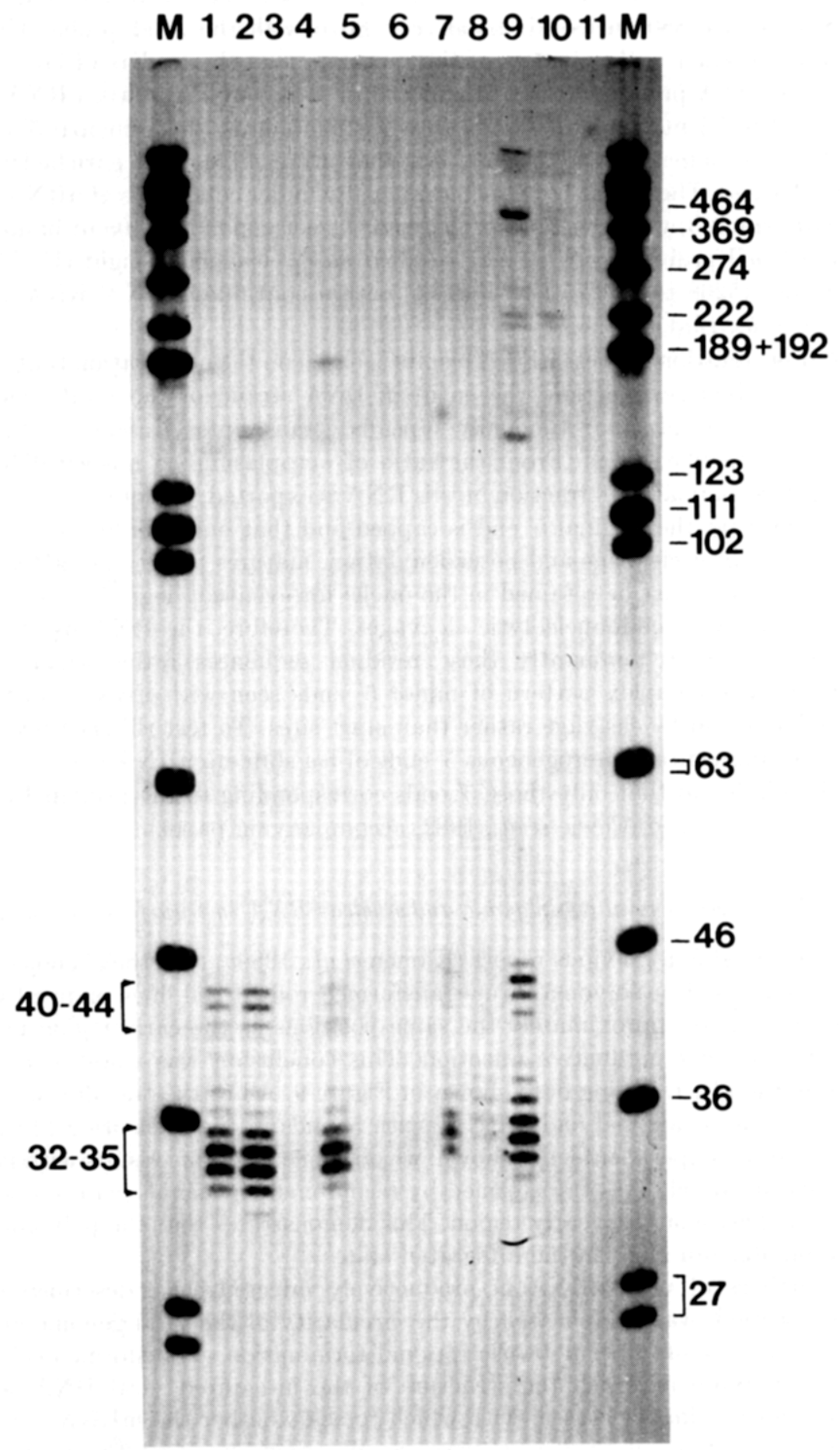

FIt: 9. 
mouse cell lines. The results of the two experiments shown in Figure 10 demonstrate, with one exception, that the predominant nRNA $5^{\prime}$ termini correspond to those of the principal mature mRNAs in the nt145 to nt 155 region.

The exceptional instance was rat line BE-1, which yielded a pattern of $S_{1}$ products strikingly similar to that of nRNA from productively infected cells, as shown in the adjacent gel track (Fig. 10). The BE-1 cell line contains two copies of the viral DNA fragment from $B c l I$ to $E c o R I$ (nt5022 clockwise to nt1565, see Fig. 1) integrated in tandem (Novak et al., 1980). Each of these fragments includes a functional early region promoter (Treisman, 1981), but lacks the major viral early region polyadenylation site. Transcripts initiated at the first promoter would continue across the second promoter region. The second promoter region therefore is in a position topographically similar to the single promoter region present in a circular genome at late times of infection. The results obtained with line BE-1 therefore support the hypothesis that the heterogeneous pattern of $5^{\prime}$ termini found with nuclear RNA from infected cells results from readthrough transcription rather than multiple initiation sites.

\section{(e) Early region $m R N A s$ produced by viable deletion mutants}

A diagram relating the positions of the wild-type polyoma virus early mRNA $5^{\prime}$ ends to other features of the beginning of the early coding region and its 5 '-flanking sequences is shown in Figure 11. The principal $5^{\prime}$ termini (ntl45 to nt156) lie approximately 30 bases downstream from a TATA box, and about 90 bases from the limit of sequences known to be important for viral DNA replication (indicated as ORIGIN in Fig. 11). This limit was defined by a number of viable deletion mutants isolated in several laboratories (Bendig \& Folk, 1979; Griffin \& Maddock, 1979; Magnusson \& Berg, 1979; Wells et al., 1979), which together define a "nonessential region" extending from after the high-affinity large T protein binding site (Gaudray et al., 1981) to just before the translational initiation codon (Fig. 11). Surprisingly, this non-essential region includes the principal mRNA 5 ' end sites and their associated TATA box. It was therefore of considerable interest to map the $5^{\prime}$ ends of the mRNAs produced by several of the viable deletion mutants in order to assess the consequences of removing a sequence element strongly implicated as an important component of eukaryotic promoters (Breathnach \& Chambon. 1981).

Fli, 9. Polyacrylamide $\left(12 \%_{0}\right) /$ urea gel fractionation of $s_{1}$-resistant IDNA after hybridization of cytoplasmic polyadenylated RNA from various polyoma virus-transformed rat or mouse cell lines to $(5)$ ${ }^{32}$ P)-labelled $D d e I-1 \dot{E}$-strand DNA. Tracks 1 and 2 . transformed rat cell lines obtained from $Y$. Ito (Ito) \& S Spurr. 1980): track 1. line tsA-RE-B3, 7.0 $\mu \mathrm{g}$; track 2, line TIAl, 8.4 $\mu \mathrm{g}$. Tracks 3 to 7 , transformed rat and mouse lines obtained from $\mathrm{M}$. Fried (Lania et al. 1980: Kamen et al. 1980a b): track 3, rat .33). $8 \cdot 2 \mu \mathrm{g}$; track 4. rat 82. $10 \mu \mathrm{g}$ : track 5, mouse ts $-3 \mathrm{~T} 3-3.10 \mu \mathrm{g}$; track 6. mouse 3T3-WT-1. 10 $\mu \mathrm{g}$ : track 7. mouse tsC-3T3-1. 8.4 $\mathrm{g}$ : track 8. mouse tsA-3T3-1.5 $\mu \mathrm{g}$ : track 9. mouse line Py6 (T. Benjamin. unpublished results: see also Kamen et al., 1974). Track 11. RNA from wild-type virus-infected 3 T6 cells. $5 \mu \mathrm{g}$. Track 12, carrier RNA only. Tracks $M$ are size markers as in Fig. 2. The lengths of principal $s_{1}$-resistant DNA products are indicated to the left of the autoradiogram. The bands in tracks 3.5 and 6 may not be clearly visible in the reproduced photograph, but were clearly the same as those in the other tracks on the original film. 

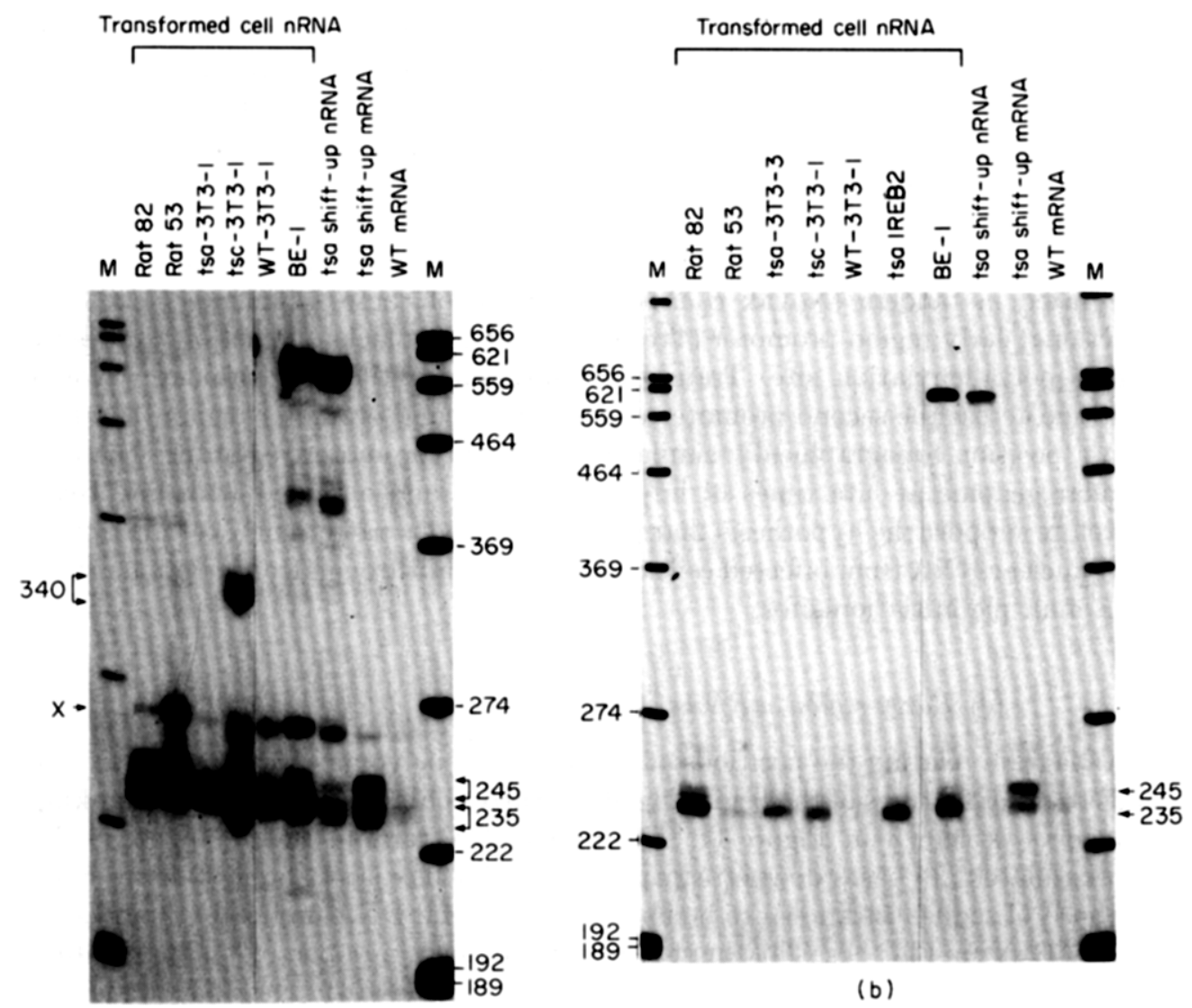

(a)

Fur. 10. Localization of the 5 ends of viral nuclear RNA in a variety of virally transformed rodent vell lines by hybridization to the HinfI DNA probe and fractionation of $S_{1}$-resistant products on a 50 , polyacrylamide gel. 'The quanties of RNA used were: rat $82.40 \mu \mathrm{g}$ : rat $53.100 \mu \mathrm{g}$; tsa3T3.1.40 $\mu \mathrm{g}$ :

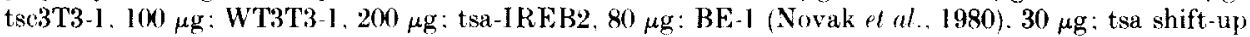
total nuclear RNA. $0 \cdot 2 \mu \mathrm{g}$ : tsa shift-up polyadenylated eytoplasmic: mRNA. $0 \cdot 2 \mu \mathrm{g}$ : wild-type mRNA. $0 \cdot 2 \mu \mathrm{g}$. (a) and (b) show duplicate experiments. The large quantities of RNA used in these anteralings required RNAase A digestion of $S_{1}$-resistant material before electrophoresis to avoid overloading the thin gels. The minor bands at approx. 340 nucleotides seen with tse3T3-1 nRNA map the position of an 11-hase deletion in the RNA relative to the probe 1)NA present beeause the exll link was transformed with strail A3 polyoma virus (M. Fried, personal communication: sese aloo Fig. II).

The three mutants selected for study (Fig. I1) all lack the TATA box. Mutants dl 17 and dl 75 also lack the mRNA 5 end site sequences. dl 17 and dl 2-19 grow nearly as well as wild-type virus, but dl 75 is partially defective in early gene expression (Bendig et al. 1980). In preliminary experiments, we examined the early region $m R N A s$ extracted from mutant-infected mouse cells 30 hours post-infection by one and two-dimensional $s_{1}$ nuclease/agarose gel mapping. We found normally spliced mRNAs with all three mutants. The 5' colinear segments of dl 17 and dl 75 early region $m$ RNAs were approximately the same length as those of wild-type virus. Mutant dl 2-19 produced highly heterogeneous 5' colinear sequences, most of 


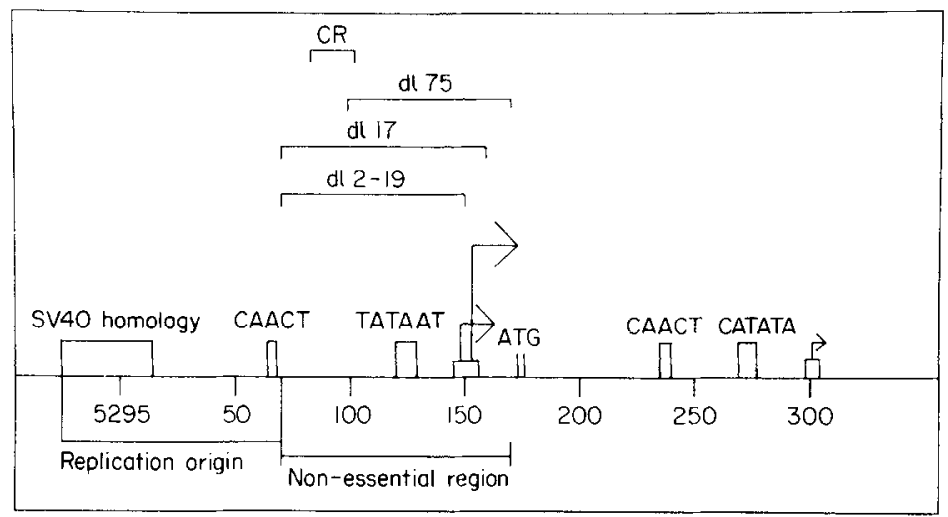

Fir, 11. Map of viable deletion mutants within the 5 ' flanking sequences of the polyoma virus early region. Nucleotides are numbered according to soeda ot al. (1980). The maximal extent of contiguous sequences essential for viral $10 \mathrm{NA}$ replication. defined by viable deletion mutants are indicated by Replication origin. Putative sequence elements (ser I)iscussion) comprising the early region promoter(s) are shown with boxes. Arrows show the positions of principal mRNA $5^{\prime}$ ends mapped in this paper. Deletions dl 75. d] 17 and dl 2-19 were deseribed by Bendig et al. (1980). The smaller deletion (CR was isolated by M. Fried (personal communication) and sequenced by one of us ( $R$. Kamen. unpublished results). The non-essential region defincd by the extent of the viable deletions is indicated.

which were longer than normal. Mutants dl 17 and dl 2-19 synthesized normal levels of early region mRNAs, but dl 75 overproduced these molecules by about tenfold at late times during infection.

The $\sigma^{\prime}$ ends of the deletion mutant mRNAs were positioned more accurately by high-resolution $S_{1}$ gel mapping. The probes used were homologous single-stranded DNA fragments, labelled at the HinfI site (cf. Fig. 1). Results obtained with dl I7 mRNA demonstrated two principal 5' termini (Fig. 12(a), track 1; Fig. 12(b), tracks 1 and 2 ) at $n t 164 \pm 2$ and $n t 58 \pm 2$. These positions are just before and just after the deleted sequences (see the diagram in Fig. 12(b)). There were a multitude of other less prominent $S_{1}$-resistant DNA products, indicative of a number of alternative 5 ' termini at the positions indicated in Figure $11(\mathrm{~b})$. The locations of the principal dl $175^{\prime}$ termini and the occurrence of minor alternatives were confirmed by primer extension analysis (Fig. 3, track 4). To ask whether any of these termini corresponded to those of minor species also present among transeripts of nondeleted viral genomes, we annealed wild-type and tsa shift-up RNA preparations to the deletion mutant HinfI DNA probe. Because $S_{1}$ nuclease does not efficiently cleave the DNA strand of a DNA-RNA hybrid opposite a single-stranded RNA loop, $S_{1}$-resistant DNA products generated with non-deleted RNA would have the same lengths as those produced by transeripts of the deletion mutant DNA with 5 ends at the corresponding positions. Hybridization of wild-type mRNA to the dl 17 DNA probe (Fig. 12(a), track 2) yielded, in addition to a very prominent product mapping the $3^{\prime}$ limit of the deletion (generated by $m$ RNAs with the principal 5 ' ends at nt 145 to nt 156 or other 5 ' ends within the deleted sequences), a distribution of minor ones consistent with the results presented in Figures 2 and 4. Comparison of the results obtained with dl $17 \mathrm{mRNA}$ and wild-type mRNA (Fig. 12(a), tracks 1 and 2 : Fig. 12(b), tracks 1,2 and 6) indicated that only the principal dl 175 


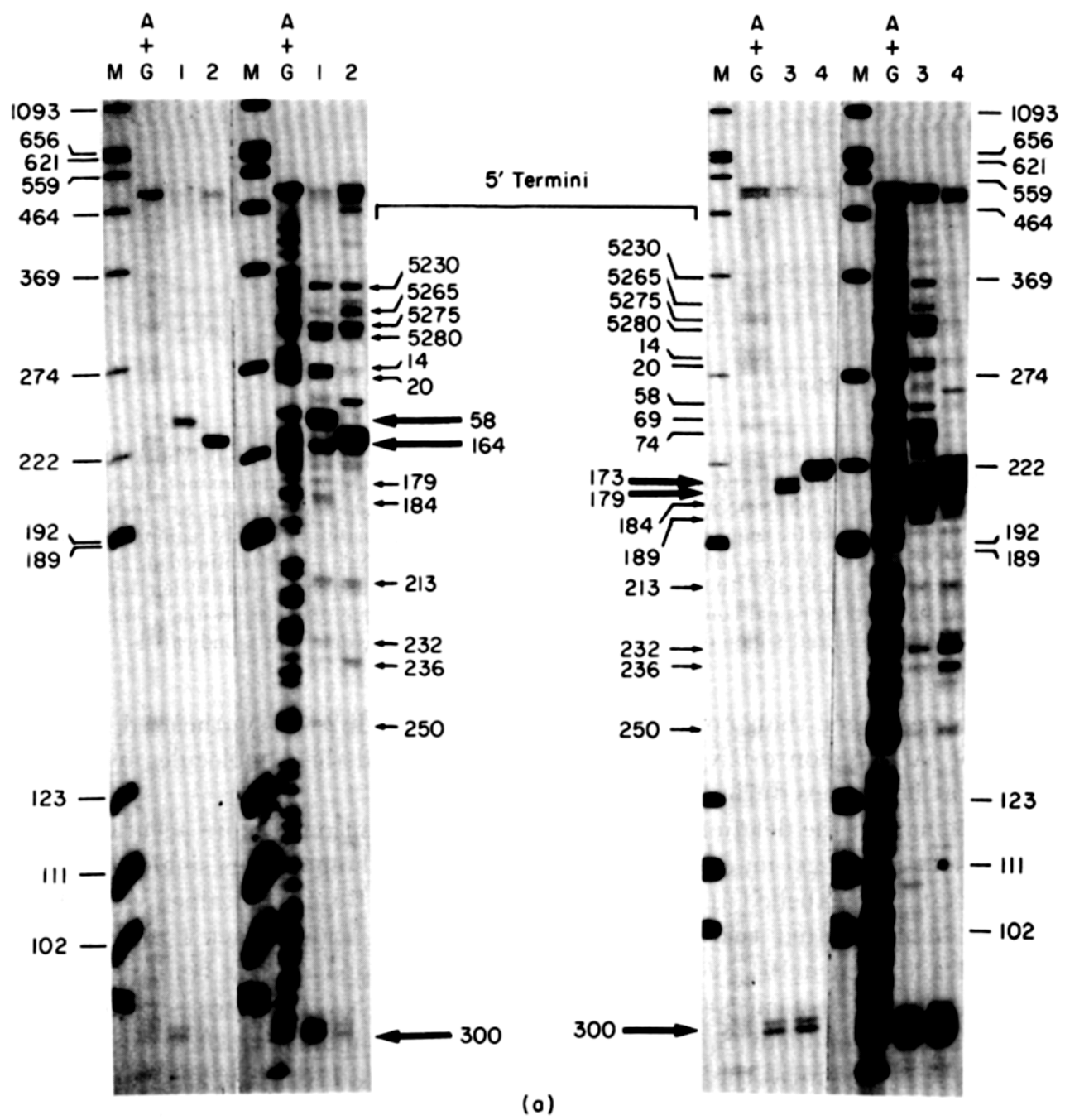

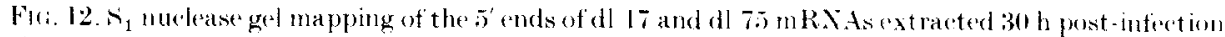
ly hybridization to homologous deletion mutant HinfI ISNA probes. (a) Track I. I pu dI IT mRNA

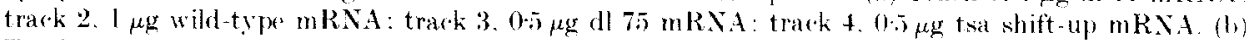

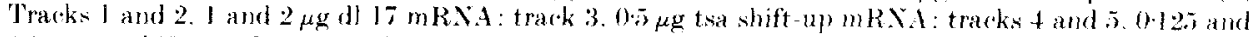
0.3 $\mu \mathrm{g}$ twa whift-up uRSA: track 6. $2 \mu \mathrm{g}$ wild-type mRNA.

termini at $n+58 \pm 2$ and $n+164 \pm 2$ were highly over-represented in the mutant mRNAs. All of the other dl 17 products align with wild-type equivalents. The mutant mRNA was also moderately enriched for termini at approximately nt 14. nt20 and nt300土2. (areful inspection of Figure 12(a) (track 2) and Figure 12(b) (tracks 3 and 6 ) revealed that the principal dl $17 \mathrm{mRNA}$ is end at nt58 2 is present at a very low level in wild-type or tsa shift-up mRNA preparations. Moreover. RNA with $5^{\prime}$ ends at this place is relatively abundant in tsa shift-up nuclear RNA (Fig. 12(b), tracks 4 and 5). Products corresponding to the dl 175 end at nt $164 \pm 2$ 


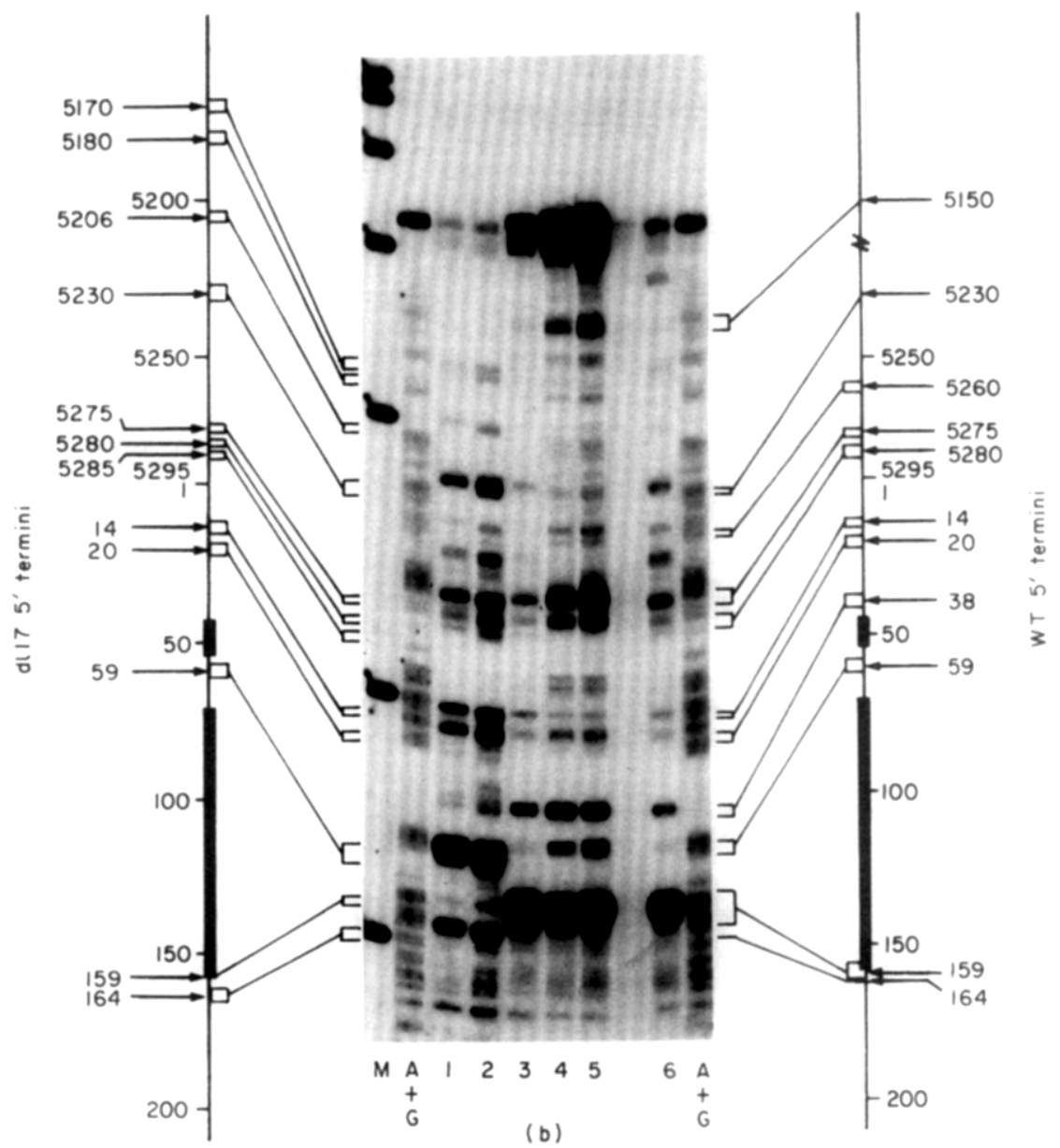

Fic: 12(b).

are also present as faint bands in control mRNA tracks, but these are difficult to see in the photographs because they lie just below the very dark bands corresponding to the $3^{\prime}$ limit of the deletion.

Similar analysis of dl 75 mRNA (Fig. 12(a), tracks 3 and 4 ) demonstrated principal $5^{\prime}$ termini mapping $3^{\prime}$ to the deletion at positions ( \pm 2 nucleotides) 173 , 179, 184 and 189. The primer extension result shown in Figure 3 (track 7) is consistent with this conclusion. Other $5^{\prime}$ ends found with the $S_{1}$ technique mapped $5^{\prime}$ to the deletion at positions 74,69 and 58 , but these were relatively minor. In addition, all of the products corresponding to minor ones in tsa shift-up mRNA were somewhat over-represented (Fig. 12(a), tracks 3 and 4). The majority of the early region $m R N A$ produced by dl 75 thus start within and after the protein synthesis initiation codon at positions 173 to 175 (ef. Fig. 11). This explains a paradox. Bendig et al. (1980) observed that dl 75 synthesized very reduced amounts of early proteins. However, we found that dl 75 over-produced early region $\mathrm{mRNA}$ by tenfold relative to the wild-type virus. We infer from the mapped 


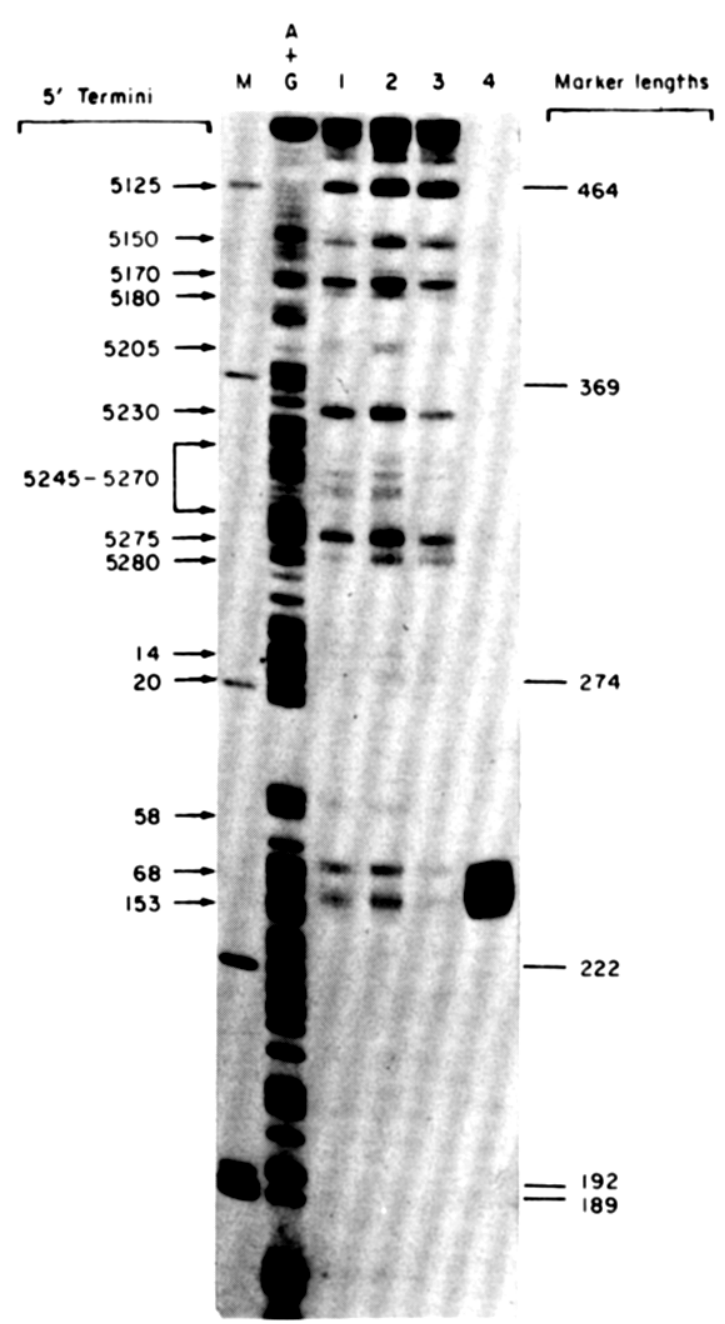

Fla. 13. S, nuclease gel mapping of the it ends of dl $2 \cdot 19$ mRNA extracted 30 h post-infection by hybridization to the dl $2-19 \mathrm{HinfT}$ IONA probe. Tracks 1 to 3.1 . 2\% and $50 \mu \mathrm{g} \mathrm{dl} 2-10 \mathrm{mRNA}:$ track 4 . $27 \mu \mathrm{g}$ wild-type mRNA. $30 \mathrm{~h}$ post-infection.

positions of the principal $5^{\prime}$ termini of dl 75 early region cytoplasmic transcripts that the majority of these "mRNAs" lack the initiation codon and thus could not be normally translated. Therefore, normal levels of large $T$ protein are not attained. and early strand transeription is not repressed.

Mutant dl 2-19 has a deletion beginning at the same point as that in $\mathrm{dl} 17$, but it retains nine more nucleotides of wild-type sequence (Fig. 11) including some of the sequences determining the principal 5 ' ends of wild-type mRNAs. The data shown in Figure 13 imply that dl 2-19 mRNAs have very heterogeneous $5^{\prime}$ ends. including major species extending well into the late region of the genome. A significant fraction of molecules had 5 ends at the $n t 54 \pm 2$ principal 5 end site. The 5 ' end at nt58 \pm 2 , which is the major one in dl $17 \mathrm{mRNA}$. was minor, while the next most 


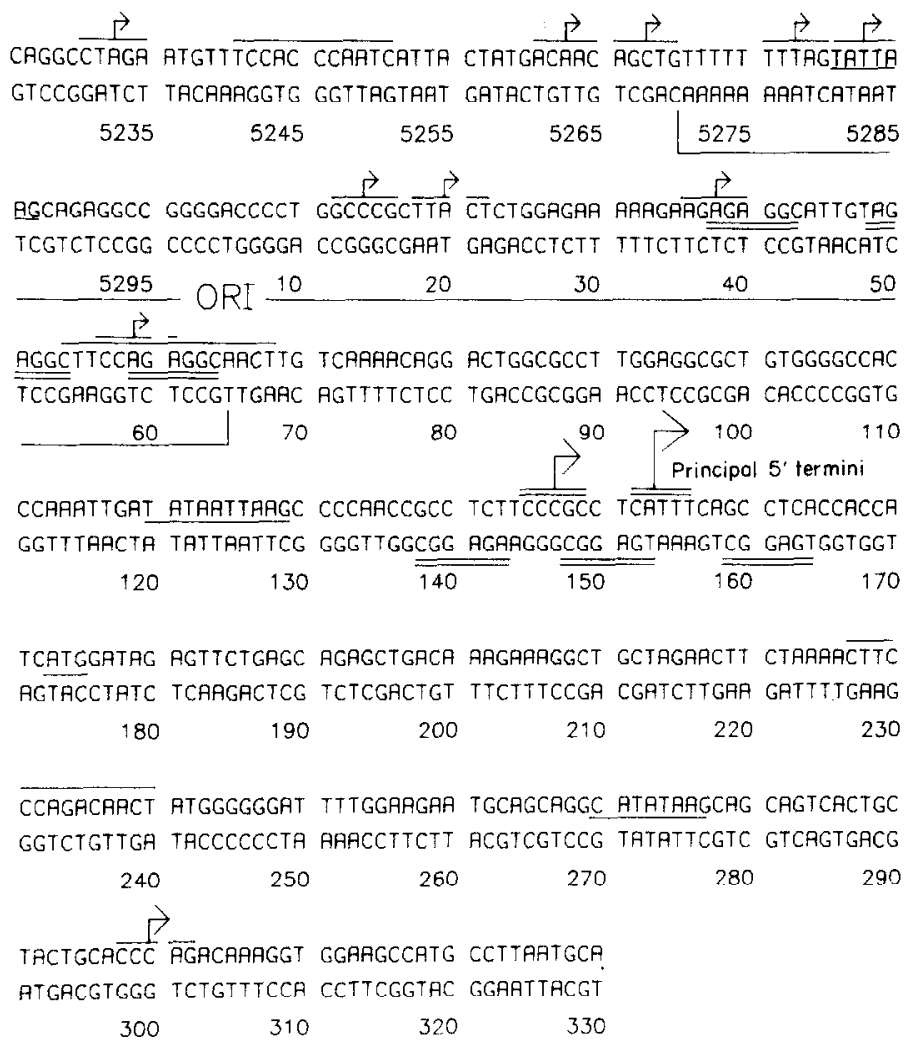

FI(i. 14. The early promoter region of polyoma virus DNA. The portion of the strain A2 genomic DNA sequence (Soeda et al. 1980) extending from just before the replication origin into the beginning of the early portion coding region is shown. The upper strand has the $5^{\prime}$ to $3^{\prime}$ polarity of early region mRNAs. Positions of $\tilde{s}^{\prime}$ termini mapped in this paper are shown with arrows above the DNA sequence. with error margins of $\pm 2 \mathrm{bp}$. The principal termini, localized by $\$_{1}$ mapping (Fig. 4) to nt $147 \pm 2$ and nt $154 \pm 2$ are shown with larger arrows. Minor 5 ' termini are indicated by smaller arrows. The data for the minor $5{ }^{\prime}$ termini upstream of the principal cap sites (at positions 5230. 5265. 5260, 5275, 5280, 14, 20. 38 and 59) are in Figs 2 (b) (track 1), 4 (tracks 1 to 4). 6 (tracks 6 to 10). 11(a) (tracks 2 and 4). 1 l(b) (tracks 3 to 5 ). Only the most prominent of the minor $5^{\prime}$ ends located downstream of the principal sites. at nt $300 \pm 2$, is included in the Figure. It was clearly detected by both $s_{1}$ gel mapping (see, for example. Fig. $2(b)$ ) and by primer extension (Fig. 3. track 8) and. moreover, was relatively enriched among mRNAs of the viable deletion mutants (Fig. 11(a). tracks 1 and 3). ()ther faint $S_{1}$-resistant INA products smaller than the principal ones (detected. for example. in Fig. 2(b)) could represent RNA nicking or internal $s_{1}$ cleavage and have therefore not been considered significant at this time. Several DNA sequences of interest are delineated. There are 3 TATA box-like sequences (underlined). at nt5278 to nt5284 at nt120 to nt129. and at nt270 to nt278. The 3 sequences ending with $\because-\mathrm{A}-\mathrm{A}$ TC boxes diseussed in the text and

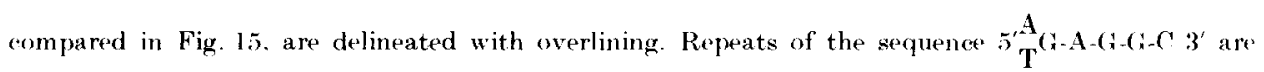
indicated by double underlining below the appropriate IDNA strand. Two of the three A-(a-A-(i-(i-C) repeats between nt 38 and $n t 64$ are required for large $T$ protein binding to the viral DNA and thus may constitute a high-affinity binding site for this molecule (Gaudray tt al., 1981). The possible significane of the related but inverted 3 -fold repeat from nt 164 to $n$ t 138 is discussed in the text. The approximate limits of contiguous sequence required for viral DNA replication. defined by viable deletion mutants (Bendig \& Folk. 1979: Bendig ot al.. 1980: Magnusson \& Berg. 1979: Griffin \& Maddock, 1979 : Tyndall et al. 1981 ; ( . Magnusson. personal communication). are indicated by (ORI. The translational initiation codon (positions 173 to 175 ) is underlined. Hyphens have been omitted for clarity. 
abundant dl $17 \mathrm{mRNA}$ 5' end (that at $n t 164 \pm 2$ ) was not found. Other $\mathrm{S}_{1}$-resistant DNA products generated with dl 2-19 mRNA map the 5 ends at positions 68, 20. $14,5280,5275$ and 5230 also present in wild-type early region $m$ RNAs at low levels (see Fig. 14). From analyses like those shown in Figure 5. we deduced that the specific products mapping apparent early mRNA 5' ends at approximately positions 5180, 5170, 5150 and 5125) (Fig. 13) are RNA-RNA annealing shadowis representing the heterogeneous $5^{\prime}$ ends of late region $L$-DNA strand transeripts: their existence proved only that 5 termini of many early region $\mathrm{mRN}$ As in dl $2 \ldots 19$ infected cells overlap those of the late region $m \mathrm{RNAs}$.

The three deletion mutants discussed above werc derived from the A3 strain of polyoma virus. This strain lacks nucleotides 44 to 54 of the $\mathrm{A2}$ strain (Soeda $4 \mathrm{al}$. 1980). which is our standard wild-type virus and the parent of conditional mutant tsa. To demonstrate that the observed differences between wild-type or tsa carly region $m R N A$ s and those of the deletion mutants are not influenced by this additional deletion, we have also characterized the $\mathrm{mRN}$ As produced by strain A3 viable mutant CR (Fig. 11). This is an A3 virus with a small additional deletion that removes nucleotides 86 to 97 . The 5 ' ends of ('R messengers we'te indistinguishable from those of wild-type $\mathrm{A} 2$ viruses (data not shown).

\section{Discussion}

This is the first of a series of papers in which we characterize the polyoma virus early region transeriptional promoter by studying its function, both in wo and in vitro, in the wild-type state and after genetic manipulation. The primary goal of the experiments reported here was to map accurately the 5 ' termini of transcripts synthesized under a variety of conditions during the productive infection of permissive cells and in virally transformed cell lines. This information was essential for the interpretation of subsequent experiments to identify DNA sequence elements responsible for the specification of transeription and its regulation by the large T protein (Tyndall et al., 1981 : de Villiers \& Schaffner, 1981: Gaudray et al.. 1981; Jat el al. 1982; P. Jat, U. Novak. A. ('owie, C. Tyndall \& R. Kamen, unpublished results). The results are of further practical utility in the construction of vectors using polyoma virus sequences to promote the expression of other eukaryotio genes.

Previous characterization of the $5^{\prime}$ termini of polyoma virus late region transcripts and of those of SV40 late and early region mRNAs (Ghosh et al.. 1978a,b, 1980a,b: Lai et al., 1978; Reddy et al., 1978,1979; (Canaani et al. 1979: Flavell et al., 1979,1980; Haegeman \& Fiers. 1978,1980; Kahana et al.. 1981: Treisman, 1980) established the precedents for both macro- and microheterogeneity. We were therefore not surprised by the rather complex results obtained. which are summarized in Figure 14. The main conclusions, discussed separately below, are (1) the principal $5^{\prime}$ termini of early region mRNAs occur at several alternative positions between $n t 145$ and $n t 156$ in the DNA sequence. We show elsewhere (Cowie et al., 1982, accompanying paper) that these 5 ' ends are capped. The principal cap sites are preceded by a TATA-like sequence. (2) Relatively minor 5 ' termini at $n t 300 \pm 2$ are present in all RNA preparations. A 
TATA-related sequence also precedes this position, but the putative termini would occur within the early protein coding sequence. (3) Other minor $5^{\prime}$ termini at several points between nt5230 and nt5260 were localized by the $S_{1}$ mapping procedure. These are particularly abundant in many preparations of RNA extracted from productively infected cells at late times during infection, when functional large $\mathrm{T}$ protein is present. The nt5230 5260 region of the genome includes a third TATAlike sequence as well as the origin of viral DNA replication. Analysis of capped $5^{\prime}$ terminal $\mathrm{T}_{1}$ oligonuclcotides (Cowie et al., 1982, accompanying paper) detected a minor cap site at ntl6, which agrees with the position of the minor 5 ' end at $n t 14 \pm 2$ deduced from $S_{1}$ mapping. This $5^{\prime}$ end occurs 31 bp downstream from the TATAbox (Fig. 14) and is located at a position analogous to that of the SV40 major early region cap sites (Ghosh \& Lebowitz, 1981). (4) Homologous sequences, including a ( ${ }^{C A} A_{T C}^{C T}$ box, oceur 40 to 66 bp before each of the three 'TATA boxes. (5) Viable deletion mutants lacking the sequences determining the principal 5 ' termini and the preceding TA'IA sequence synthesize mRNAs with slightly or highly heterogeneous termini. Each mutant produces a different characteristic set of termini, which in all cases correspond to very minor $5^{\prime}$ ends detectable among transcripts of wild-type viral DNA.

(a) The principal 5' termini of polyoma virus early region transcripts

Results of $s_{1}$ nuclease and primer extension measurements suggested that the principal $5^{\prime}$ termini of mRNAs synthesized during productive infection occur at multiple positions between nt 145 and $n t 156$ in the genomic DNA sequence, within a region that is 23 to $36 \mathrm{bp}$ after a TATA box-like element (Fig. 13). $\mathrm{S}_{1}$ mapping data, such as shown in Figure 4 (track 3 ), suggested that there were a minimum of two 5 ' ends, at nt147 \pm 2 and at nt $154 \pm 2$ (Fig. 14). This conclusion also pertained to $\mathrm{mRNAs}$ and nuclear RNAs present in a variety of virally transformed cell lines (Figs 9 and 10). The present data, however, do not allow the exact assignment of terminal nucleotides or demonstrate that these termini are capped. We have directly analysed the terminal $T_{1}$ oligonucleotides of chemically decapped and $\left(5^{\prime}\right.$ ${ }^{32} \mathrm{P}$ )-labelled tsa shift-up mRNAs. These experiments are described in the accompanying paper, but the conclusions inferred are germain to the present discussion and will therefore be summarized briefly here. We found that the cap sites correspond to the $A$ residue at $n t 153$, the $U$ residue at $n t 151$, the $C$ residue at nt150, and to the $G$ residue at nt 148 (see Fig. 13). The two pyrimidine cap sites were relatively minor. We also observed, however, that a significant proportion of the mRNAs had capped $\tilde{5}^{\prime}$ ends apparently formed by the "back-slippage" of oligonucleotide primers corresponding to different lengths of the sequence from the $A$ residue at nt 153 to the $\mathrm{C}$ residue corresponding to $\mathrm{nt} \mathbf{1 5 6}$. We further found that carly region transeripts initiated in the HeLa cell system in vitro (Manley et al., 1980), which faithfully transcribes the polyoma virus early promoter (Jat et al., 1982), had a very similar distribution of (apped 5 termini, including those produced by back-slippage during RNA chain initiation. In the system in vitro. the relative proportions of caps at different nucleotides from 148 to 153 could be 
manipulated by varying nucleoside triphosphate concentrations. This established both that the cap sites correspond to initiation sites, and that the bias in favour of the A cap at nt153 observed in vivo is more probably a reflection of nuclear triphosphate levels than an inherent specificity of RNA polymerase II.

Comparison of the principal $5^{\prime}$ ends of early region mRNAs synthesized at late times during infection in the presence or absence of functional large $T$ protein. which is known to regulate early gene expression (Cogen, 1978; Kamen et al.. $1980 a, b)$, demonstrated significant differences in the distribution of termini within the ntl48 to ntl53 region (Figs 2 and 4 ). In particular, only the mRNA overproduced after inactivation of the large $\mathbf{T}$ protein had large relative amounts of the $S_{1}$ product corresponding to the $G$ terminus at nt 148 (see Fig. 4, tracks 3 and 8). Further experiments are required to determine the mechanistic basis of this phenomenon.

\section{(b) Alternative minor 5 termini within the coding region}

In all $S_{1}$ nuclease or primer extension analyses of RNA from infected cells, we detected a minor $5^{\prime}$ end located at nt300 \pm 2 (Fig. 14). Since this was found with both techniques, it is probably not a methodological artifact. This conclusion is strengthened by the observations that (1) the minor $5^{\prime}$ end occurs at the same relative level among transeripts produced in vitro (Jat et al., 1982). (2) The terminus at $\mathrm{nt} 300 \pm 2$ is much less abundant in nuclear RNA (Fig. 7, nRNA tracks). showing that it is not a result of $S_{1}$ nuclease "cut-through" or reverse transcriptase stops. (3) Certain deletion mutations that virtually abolish initiation at the principal cap sites in vitro still yield normal levels of this minor $5^{\prime}$ end (P. Jat $t$ t al.. unpublished results). (4) A TATA box sequence (C-A-T-A-T-A-A: cf. Fig. 13) occurs about 30 bp 5 to position 300 (Fig. 14). We infer that this $5^{\prime}$ end indicates a second early region initiation site. This, however, would lie some 125 bp within the early region coding sequences. Its physiological significance is unknown.

\section{(c) The significance of the "upstream" is termini}

Our initial eomparisons of early region mRNAs synthesized under different. conditions at late times during infection (see, for example, Figs 6 and 7 ) suggested that the occurrence of longer messengers with $5^{\prime}$ ends between nt5230 and nt5260 (the replication origin region, as illustrated in Figs 11 and 14) was negatively correlated with the presence of functional large $T$ protein. This implied the intriguing possibility that large $T$ protein repression shifted transcription from the principal to a minor upstream promoter region. Similar conclusions have been reported with the related virus SV40 (Ghosh \& Lebowitz, 1981). As we now have major reservations concerning this interpretation of the data, it is important to take this opportunity to discuss the situation in detail.

We first compare the polyoma virus early promoter region with that of SV 40 . The polyoma virus principal cap sites are some 150 bp remote from the replication origin (Figs 11 and 14) within a region not homologous to any sequences found in SV40 DNA. The SV40 principal eap sites (Ghosh \& Lebowitz. 1981), by contrast. are very near the highly conserved papovavirus origin region, which contains a 
TATA box-like element (nt5278 to nt5283 in polyoma virus DNA, see Fig. 14). The SV40 principal cap sites are about $30 \mathrm{bp}$ after the counterpart of this element in SV40 DNA. Two of the minor polyoma virus upstream $5^{\prime}$ termini indicated in Figure 14, at ntl4 22 and at nt20 2 (see Fig. 2(b), track 3; Fig. 12(a), tracks 2 and 4 ; Fig. 12(b), track 3 ; for data supporting these assignments), are at positions in the polyoma sequence analogous to the $\mathbf{S V 4 0}$ principal cap sites. The 5 end at $n+14 \pm 2$ has been correlated with a very minor capped $5^{\prime}$ end at the $G$ residue corresponding to ntl6 (see Fig. 14) found by analysis of terminal $\mathrm{T}_{1}$ oligonucleotides (Cowie et al., 1982). We infer that the origin region of polyoma virus DNA retains some of the promoter function of the homologous sequences in SV40 DNA, but that this polyoma promoter is very inefficient. Of the other minor 5 termini indicated by $S_{1}$ nuclease analysis, those at about nt5275 and nt5280 (Fig. 14 for relevant data; see, for example. Fig. 12(b)) probably represent the cleavage of a highly $\mathrm{U}$-rich region within continuous hybrid. A similar phenomenon has been reported with $\mathrm{SV40}$ (Hansen et al., 1981). This demonstrates only that some RNA molecules extend to positions beyond nt5275. The minor 5 ' termini at nt5260 and nt5230 in the polyoma sequence (Fig. I4, of. Fig. 12(b), track 6) may correspond to the upstream termini identified in SV40 by Ghosh \& Lebowitz (1981). but we have no evidence that they are indeed cap sites. We have, however. excluded the possibility that these polyoma virus $5^{\prime}$ termini are artifactually produced by RNA-RNA self-annealing (see Fig. 5). We know further that polyoma virus $m R N A$ preparations that contain relatively large amounts of longer species include molecules with $5^{\prime}$ ends extending beyond nt5230. These are not indicated in Figure 14, because RNA-RNA annealing prevented the mapping of their 5 ' termini by the $S_{1}$ or primer extension techniques.

The following observations caution against the interpretation that large $\mathrm{T}$ protein repression causes a shift towards an upstream promoter: (1) the recovery of polyadenylated cytoplasmic $m R N$ As with the longer 5 ' regions was variable among many RNA preparations: (2) nuclear viral $\mathrm{RNA}$, at late times during infection. comprised giant species produced by continuous transeription around the circular genome. These molecules had very heterogeneous $5^{\prime}$ termini, many of which correlated with the 5 ' ends of the longer "cytoplasmic" mRNAs. There was far more nuclear than cytoplasmic RNA at such late times, making contamination a major problem. Only those $5^{\prime}$ ends of nuclear RNA rorresponding to the principal cap sites were indeed capped (Cowie et al., 1982. accompanying paper). We therefore suspect that the other termini are processing rather than initiation sites. (3) Early region transcripts with $5^{\prime}$ ends upstream of the principal cap sites are uneommon among the various transformed cell lines studied (ef. Figs 9 and 10). One cell line, however, produced nRNA molecules with heterogeneous 5 ' termini essentially identical to those present at late times during productive infection (Fig. 10, track BE-1). This cell line (BE-1: Novak et al., 1980) contains two fragments of viral DNA (extending from about nt 5022 clockwise to nt1560; see Fig. 1) integrated in tandem; transeripts initiated at the first promoter region would readthrough the second promoter. Moreover, although BE-1 cells produce transcripts with the longer $5^{\prime}$ termini. they do not synthesize functional large $\mathrm{T}$ protein. 
These observations, taken together, suggest that the production of "mRNAs" with longer 5 ' regions at late times during infection results from inefficient termination. transeription around the eireular genome, and the subsequent cleavage of the giant transcripts at a multitude of points, some of which are in the origin region. Whether such cleavage products can serve as mRNAs if exported to the cytoplasm is not known. Fenton \& Basilico (personal communication) have found that longer early region species can be detected on gels fractionating cytoplasmic RNA extracted from cells at late times during infection. They also noted that there is an open codon reading frame (from 105255 to ntl 22 ) a vailable in such molecules, which could encode an additional viral gene product. Several viable deletion mutants exist that interrupt this potential coding region. however. and therefore the putative protein cannot be essential.

\section{(d) Consensuss sequences}

We have identified three regions of polyoma virus DNA that are likely to include early mRNA cap sites (Fig. 14): the "SV40-like" region from ntl6 to nt20, the principal cap site region from ntl48 to ntl53, and the further minor 5 ' end at nt300 \pm 2 . Each of these follows a sequence related to the TATA consensus by the usual distance. A second conserved sequence element. known as the CCAAT box (Efstratiadis et al. 1980): Benoist ot al. 1980): (orden of al. 1980: Breathnach \& Chambon, 1981), has been found in most but not all eukaryotic RNA polII genes. usually about 65 to $80 \mathrm{bp}$ upstream of the rap site. Deletion of this sequence reduces globin gene expression in vivo (Dierks et al. 1981 : Mellon et al., 1981), and it is included within a region required for Herpes simplex virus thymidine kinase gene expression (McKnight et al., 1981). The three polyoma TATA boxes are preceded by homologous sequences ending with ( $\mathrm{AA} \mathrm{TC}_{\mathrm{C}}^{\mathrm{CT}}$, which are located 40 to 66 bp upstream of the TATA boxes or 70 to $96 \mathrm{bp}$ upstream of the cap sitcs (Fig. 14). As illustrated in Figure 15, there is also conservation of sequence just 5 to

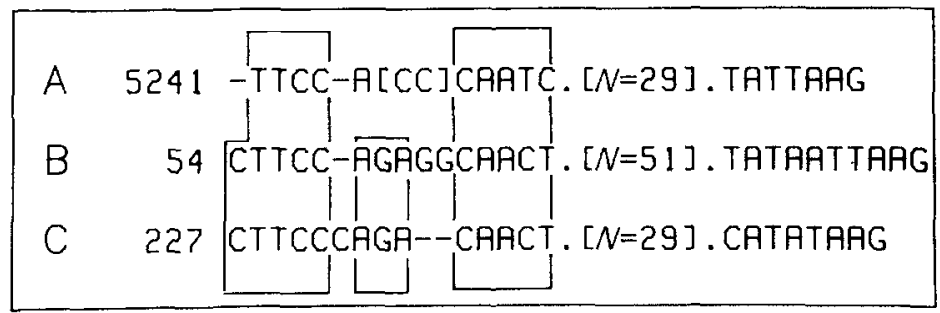

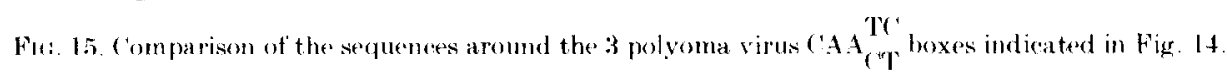
The first muleotide of each line is given in standard nucleotide mumbers to permit relation of this diagram to the seguenes shown in Fig. 14. $X$ is the distane from the end of the "A. TC box to the begimning of the TA'TA box. Hyphens have been mitted for clarity 
the three $\mathrm{CAA}_{\mathrm{TC}}^{\mathrm{CT}}$ boxes. The functional significance of these homology regions is under investigation.

(e) The expression of viable deletion mutants

The principal early region cap sites and their TATA box are within a region defined as non-essential for early gene expression by a number of viable deletion mutants (Bendig \& Folk, 1979 ; Bendig et al., 1980; Magnusson \& Berg, 1979). This is perhaps not surprising, since it is now known that the removal of such elements from several different cellular and viral genes does not abolish transcription in vivo (Grosschedl \& Birnstiel, 1980b; Benoist \& Chambon, 1981 ; McKnight et al., 1981). Mapping of the 5 ' ends of early region $m$ RNAs produced by three of the polyoma viable deletion mutants (dl 75, dl 17, dl2-19; Bendig et al., 1980) showed that each mutant synthesized messengers with a particular set of slightly (dl 75 and dl 17) or highly heterogeneous (dl 2-19) $5^{\prime}$ termini. These termini, in all instances. corresponded to the overproduction of very minor alternative $5^{\prime}$ ends also present among transcripts of wild-type DNA. Mutant dl 2-19 retains the DNA sequence corresponding to the A cap site at nt 153. This site continued to function without the TATA box, but became one of a great number of alternative possibilities. As the polyoma virus early promoter is negatively regulated by one of its gene products, it is difficult to assess from the present data whether the deletions reduce inherent promoter efficiency. Results of transient expression assays, in which plasmids containing one of the mutants studied here (dl 75) as well as a number of further mutants (Tyndall et al., 1981) were transfected into non-permissive HeLa cells, strongly suggest, however, that the efficiency of the early promoter is not substantially reduced by removal of the TATA element. Our results are thus in agreement with the view (Grosschedl \& Birnstiel, 1980b; Benoist \& Chambon, 1981 ; McKnight et al., 1981) that sequence elements other than the TATA box are important in the quantitative transcription control of a certain region, whereas the TATA element serves to specify particular initiation sites from among several alternatives. The localization of the other control elements of the polyoma early promoter is the subject of a separate publication (Tyndall et al.. 1981).

\section{(f) Speculations on large $T$ protein autoregulation}

The regulation of SV40 early gene expression by its large T protein is relatively well understood. There are three binding sites for this protein across the SV40 origin region (Tjian, 1978,1979). These span the major $\$ V 40$ early region cap sites and the TATA box that precedes them. Addition of purified SV40 large $\mathrm{T}$ protein (or the similar D2 hybrid protein) to transcription systems in vitro specifically represses initiation of SV40 early region transeription (Rio et al, 1980; Myers et al 1981; Hansen et al., 1981). Equivalent experiments are not yet possible with polyoma virus because its large $\mathrm{T}$ protein has not been purified. Gaudray et al. (1981), however, recently localized a high-affinity binding site for polyoma virus large $T$ on the viral DNA. This site comprises two copies of the A-G-A-G-G-C. 
sequence that is repeated three times between nt38 and nt64 in the strain A2 INA sequence (see Fig. 14). As the principal polyoma virus cap sites mapped in this paper are some $90 \mathrm{bp}$ distant from the high-affinity large $\mathrm{T}$ protein binding site, it seems likely that the mechanism of autoregulation will differ from that of SV40. We note in Figure 14 that the sequence $\mathrm{T}-\mathrm{G}-\mathrm{A}-\mathrm{G}-\mathrm{G}-\mathrm{C}\left(\mathrm{N}_{5}\right) \mathrm{T}-\mathrm{G}-\mathrm{A}-\mathrm{G}-\mathrm{G}-\mathrm{C}\left(\mathrm{N}_{4}\right) \mathrm{A}-\mathrm{G}-\mathrm{A}-\mathrm{G}-$ $\mathrm{G}-\mathrm{C}$, which is strikingly homologous to the high-affinity binding site except for $\mathrm{T}$ to A transversions at the beginning of the first two A-G-A-G-G-C repeats, occurs across the principal cap site region (ntl64 to nt138). However, the sequence is in the inverted orientation (Fig. 14). It will obviously be of considerable interest to determine whether polyoma large $\mathrm{T}$ protein represses transcription by binding to this inverted imperfect duplication of the high-affinity binding site.

We thank Mrs A Symons. Miss P. Morgan and Miss (4. Yiangou for their assistance in the preparation of this manuscript.

Note added in proof: Recent experiments done in our laboratory (A. Cowie, F. (haudry. S. Dilworth, S. Lupton \& R. Kamen, unpublished observations) and by others (A. Scheller \& (. Prives personal communication) have confirmed the existence of the predicted second independent binding site for the large $\mathrm{T}$ protein in polyoma virus DNA.

\section{REFERENQ'ES}

Acheson, ‥ H. \& Mieville, F. (1978). J. Firol 28. 88.7894.

Alwine. J. C.. Reed. S. I. \& Stark. G. R. (1977). \% Virol. 24, 22-27.

Baker. (. (. \& Ziff. E. B. (1981). J. Mol. Biol. 149. 189 221.

Bendig. M. M. \& Folk. W. R. (1979). J. Virol. 32. 530-535.

Bendig. Y. M., Thomas. T. \& Folk, W. R. (1980). Cell. 20, 40I 4(0).

Benoist. (. \& Chambon. P. (1981). Nature (London), 290. 304 309.

Benoist, (... ()'Hare. K., Breathnach. R. \& Chambon, P. (1980). Nucl. Acids Res. 8. 127 143.

Berk, A. J. \& Sharp. P. A. (1977). Cell, 12, 721-732.

Breathnach, R. \& Chambon. P. (1981). Anmu. Rev. Biochem. 50. 349838

Canaani, D.. Kahana, C.. Mukamel. A. \& Groner, Y. (1979). Proc. Sat Acud Sri. C.N.A. 76. $3078-3082$.

Cogen. W. (1978). Virology. 85. 222-230.

Corden. J.. Wasylyk, B., Burhwalder, A. Sassone-Corsi. P'. Kiedinger. C. \& ('hambon, P. (1980). ścience, 209 , $1406-1414$.

Cowie. A.. Tyndall, (C \& Kamen, R. (1981). Nuel trids Res. 9. 6305-6322.

('owie, A.. Jat. P. \& Kamen, R. (1982). J. Mol. Biol. 159. 225)-255.

Deininger. P. Esty, A.. Lal'orte, P. \& Friedmann, T. (1979). Cell, 18, 771-779.

de Villiers. J. \& Schaffner. W. (1981). Nuel. Acids. Res. 9, 6251-fi264.

Dierks, P.. van Ooyen. A.. Mantel. N. \& Weissmann, C. (1981), Proc . Tat Acad sici. L.S.A. 78. $1411 \cdot 1415$.

Efstratiadis. A., Posakony. .J. W.. Maniatis, T.. Lawn. R. H.. OConnell. ('.. Npritz. R. A. DeRiel, J. K.. Forget, B. ( .. Weissmann, S. M.. Slightom. (C. ('. \& Proudfoot. N. J. (1980). (Cell. 21. 653-668.

Favaloro, J.. Treisman, R. \& Kamen. R. (1980). Methods E'nzymol. 65. 718749

Flavell. A. J.. Cowie. A., Legon. S. \& Kamen. R. (1979). Cell. 16. 357 371.

Flavell. A. J.. Cowie. A. Arrand, J. R. \& Kamen. R. (1980), I. Frol. 33, 902-908.

Fried. 11. (1965). Virology. 25. 669-671.

Friedmann. T', Esty. A. LaPorte, P. \& Deininger. P'. (1979). ('ell. 17, 715-724.

Gaudray, P.. Tyndall, C. Kamen, R. \& Cuzin, F. (1981). Nucl Acids Res. 9, 56975710

Ghosh. P. K. \& Lebowitz. P. (1981). J. Virol. 40. 224 240. 
Ghosh, P. K.. Reddy. V. Swinscoe, J.. Choudary, P., Lebowitz. P. \& Weissmann. S. (1978a). J. Biol. Chem. 253, 3643-3647.

(ihosh, P. K. Reddy V. Swinseoe, J., Lebowitz, P. \& Weissmann, S. (1978b). J. Mol. Biol. 126, $813-846$.

(ihosh. P. K.. Reddy, V.. Piatak, M., Lebowitz, P. \& Weissmann. S. M. (1980a). Methods Enzymol. 65. 580-594.

Ghosh. P. K.. Piatak. M., Reddy. V.. Swinscoe, J.. Lebowitz. P. \& Weissmann. S. M. (1980b). Cold spring Harbor Symp. Quant. Biol. 44. 31-39.

Gretz, M., Land, H., Giesecke. K.. Schutz, G., Jung. A. \& Sippel, A. (1981). Cell, 25, 743-752.

Griffin. B. E. \& Maddock, C. (1979). J. Virol. 31, 645-656.

Grossehedl, R. \& Birnstiel, M. L. (1980a). Proc. Nat. Acad. S'ci. T.A'.A. 77. 1432-1436.

Grosschedl, R. \& Birnstiel. M. L. (1980b). Proc. Nat. Acad. Sci. T.S'.A. 77. 7102-7106.

Haegeman, (r. \& Fiers. W. (1978), J. Virol. 25. 824-830.

Haegeman. (: \& Fiers. W. (1980). J. Virol. 35. 95)-961.

Hansen, C.. Tenen, D. G., Livingston. D. M. \& Sharp. P. A. (1981). Cell, 27. 603-612.

Hentschel. C. Irminger. J.C.. Bucher, P. \& Birnstiel. M. L. (1980). Nature (London), 285. $147-151$.

Ito. Y. \& Spurr. N. (1980). Cold S'pring Harbor Symp. Quant. Biol. 44, 149-157.

Jat, P.. Roberts, J. W.. (ow ie. A. \& Kamen, R. (1982). Nucl. Acids Re's. 10, 871-887.

Kahana, (.. Gidoni. D.. Canaani, D. \& Groner. Y. (1981). J. Virol. 37, 7 -16.

Kamen. R. I.. Lindstrom. D. M.. Shure. H. \& Old. R. (1974). Cold spring Harbor symp. Quant. Biol. 39, 187198.

Kamen. R. I., Sedat, J. \& Ziff. E. (1976). J. Virol. 17, 212-218.

Kamen. R. I., Favaloro, J. \& Parker. J. (1980a), J. Virol. 33. 637-65].

Kamen. R. I.. Favaloro, J. M., Parker, J. T.. Treisman, R. H. Lania, L.. Fried, II \& Mellor, A. (1980b). Cold Spring Harbor Nymp. Quart. Biol. 44. 63-75.

Khoury (A. \& Vay. E. (1977). J. Virol. 23. $167-176$.

Lai. C. J.. Dhar. R. \& Khoury G. (1978), Cell. 14. 971-982.

Lania, L. Hayday. A.. Bjursell, G.. Gandini-Attardi. D. \& Fried, M. (1980). Cold spring Harbor Symp. Quant. Biol. 44, 597-603.

Magnusson, (A. \& Berg, P. (1979). J. V'irol. 32. 523-529.

Malek, L. T., Eschenfeldt. W. H.. Munns. T. W. \& Rhoads. R. F. (1981). Nucl. Acids Res. 9. $16.57-1673$.

Manley, J. L.. Fire, A., Cano. A., Sharp. P. A. \& Gefter, 11. L. (1980). Proc . Vat. Acad sci., I.S.A. 77, 385;-3859.

Maxam. A. \& (4ilbert. W. (1980). Methods Enzymol. 65. 499-560.

MeKnight. S. L.. (avis, E. R.. Kingsbury. R. \& Axel, R. (1981). Cell. 25. 385-398.

Mellon. P.. Parker. V.. Gluzman, Y. \& Maniatis, T. (1981). Cell, 27, 279-288.

Myers. R. M.. Rio, D. C.. Robbins, A. K. \& Tjian. R. (1981). Cell. 25. 273-284.

Novak. U., Dilworth. S. M. \& Griffin, B, F. (1980). Proe. Nint Aead. Sei. U.S.A. 77, 3278 3282 .

Reddy. V, B.. (thosh. P. K.. Lebowitz. P. \& Weissmann, S. M. (1978). Nucl. Acids Res. 5. $4195-4214$.

Reddy. V. B., (xhosh. P. K.. Lebowitz. P.. Piatak. M. \& Weissmann, S. M. (1979). J. Virol. 30. $279-296$.

Reed. S. I. Stark. (G. R. \& Alwine. J. C. (1976). Proc. Nat. Acad Sci. U.S.A. 73, 3083-3087.

Rio. I). Robbins. A.. Myers. R. \& Tjian. R. (1980). Pror. Nat Arad Sci V.S. A. 77. 5706.5710 .

Sanger, F. \& Coulson, A. R. (1978). FE BS Letters. 87. 107*110.

Soeda, E.. Arrand, J. R.. Smolar, N.. Walsh. J. E. \& (iriffin, B. E. (1980). Nature (London). 283. 445-453.

Sollner-Webb, B. \& Reeder. R. H. (1979). Cell, 18. 485-499.

Tegtmeyer. P.. Schwart\%. M.. Collins, J. K.\& Rundell, K. (1975). J. Virol, 16. 168-178.

Tyndall. (... La Mantia, G.. Thacker, (.. H.. Favalore. J. \& Kamen. R. (1981). Nucl. feids Res. 9. 62:31-6250. 
Tjian, R. (1978). (ell. 13. 165-179.

Tjian, R. (1979). Cold spring Harbor Symp. Quant. Biol. 43, 65.5-662.

Tooze. I. (1980). Editor of The Molecular Biology of Tumor l'iruses-IN-t Tumor liruses. Part 2. Cold Spring Harbor Laboratory Press. (oold Sipring Harbor.

Treisman. R. H. (1980). Nurl. Acids Res. 8. $4867 \% 4888$.

Triesman. R. H. (1981). Ph.I) thesis. Iniversity (ollege. London.

Treisman, R. H.. Cowie. A. Favaloro. J. .I.. Jat. P. \& Kamen. R. (1981). . Mol. A ppl tron. 1. 83992 .

Weaver. R. F. \& Weissmann, (1. (1979). Nuel. Acids Res. 7. 11751193.

Wells. R. D.. Hutchinson. V. A. \& Eekhart. W. (1979). J I Hol 32 517 522. 